\title{
SPATIOTEMPORAL HETEROGENEITY DECOUPLES INFECTION PARAMETERS OF AMPHIBIAN CHYTRIDIOMYCOSIS
}

\author{
Kirsten M. McMillan ${ }^{1,2}$, David Lesbarrères², Xavier A. Harrison ${ }^{1,3}$, \\ \& Trenton W. J. Garner ${ }^{1}$ \\ ${ }^{1}$ Institute of Zoology, Zoological Society of London, London NW1 4RY, UK. \\ 2 Department of Biology, Laurentian University, Sudbury, Ontario P3E 2C6, Canada. \\ ${ }^{3}$ University of Exeter, Stocker Road, Exeter EX4 4QD, UK.
}

\section{Corresponding author:}

Kirsten M. McMillan

Dogs Trust, 17 Wakley Street, London EC1V 7RQ

kirsten.marie.mcmillan@gmail.com 


\section{$1 \quad \underline{\text { Abstract }}$}

2 1. Emerging infectious diseases are responsible for declines in wildlife populations around the globe. Mass mortality events associated with emerging infectious diseases are often associated with high number of infected individuals (prevalence) and high pathogen loads within individuals (intensity). At the landscape scale spatial and temporal variation in environmental conditions can alter the relationship between these infection parameters and blur the overall picture of disease dynamics.

2. Quantitative estimates of how infection parameters covary with environmental heterogeneity at the landscape scale are scarce. Predicting rates of pathogen transmission and identifying wild populations at risk of disease epidemics requires that we elucidate the factors that shape, and potentially decouple, the link between pathogen prevalence and intensity of infection over complex ecological landscapes.

3. Using a network of 41 populations of the amphibian host Rana pipiens in Ontario, Canada, we present the spatial and temporal heterogeneity in pathogen prevalence and intensity of infection of the chytrid fungus Batrachochytrium dendrobatidis $(B d)$, across a 3-year period. We then quantify how covariation between both infection parameters measured during late summer, are modified by previously experienced spatiotemporal environmental heterogeneity across 14 repeat sampled populations.

4. Late summer $B d$ infection parameters are governed, at least in part, by different environmental factors operating during separate host life history events. Our results provide evidence for a relationship between $B d$ prevalence and thermal regimes prior to host breeding at the site level, and a relationship between intensity of infection and aquatic conditions (precipitation, hydroshed size and river density) throughout host breeding period at the site level. This demonstrates that 
26 microclimatic variation within temporal windows, can drive divergent patterns of 27 pathogen dynamics within and across years, by effecting changes in host behaviour 28 which interfere with the pathogen's ability to infect and re-infect hosts.

29 5. A clearer understanding of the role that spatiotemporal heterogeneity has upon 30 infection parameters will provide valuable insights into host-pathogen 31 epidemiology, as well as more fundamental aspects of the ecology and evolution of interspecific interactions.

33 Keywords: Batrachochytrium dendrobatidis, spatiotemporal, environmental 34 heterogeneity, host phenology, prevalence, intensity of infection, mixed-effects model, 35 Rana pipiens. 
Emerging infectious diseases (EIDs) pose a significant threat to the conservation of global biodiversity and are responsible for species declines and extinctions around the globe (Fisher et al., 2012). EIDs are commonly characterized by both efficient pathogen transmission, manifesting as high prevalence, and accumulation of pathogen loads within infected hosts, i.e. high intensity of infection. Though prevalence and intensity of infection may be tightly coupled at the local scale, heterogeneity in both landscape structure and climatic patterns can alter a pathogen's life history and disrupt the association between these two infection parameters at larger spatial scales (Ostfeld et al., 2005). Both infection parameters may independently respond to multiple, interacting, and often nonlinear environmental variables in very different ways (Altizer et al., 2013), meaning complex ecological landscapes may constrain pathogen distribution and the epidemic potential of an infectious disease (Walther et al., 2002). Though it has long been recognized that environmental heterogeneity has the ability to modify the strength of interactions between hosts and pathogens, quantitative estimates of how infection parameters covary with environmental variability at the landscape scale are scarce. If we are to predict rates of pathogen transmission and eventually identify wild populations at risk of epidemics, we must elucidate factors that shape, and potentially decouple, the link between pathogen prevalence and intensity of infection over highly heterogenous ecological landscapes. Using a network of 41 populations of the amphibian host Rana pipiens (R. pipiens, Northern Leopard Frog, formerly Lithobates pipiens; Yuan et al., 2016) in Ontario, Canada, we present the spatial and temporal heterogeneity in pathogen prevalence and intensity of infection of the chytrid fungus Batrachochytrium dendrobatidis (Bd; Longcore et al., 1999), across a 3-year period. We then quantify how covariation between both infection parameters measured 
61 during late summer, are modified by previously experienced spatiotemporal environmental heterogeneity across 14 repeat sampled populations.

$B d$ has contributed to the decline of at least 501 amphibian species over the past half-century, including 90 species that are confirmed or presumed extinct in the wild (Scheele et al., 2019). One of the most striking features of $B d$ is the variability in outcome of infection that has been observed among populations, within a species. For example, the spread of $B d$ in common midwife toad (Alytes obstetricans) populations in Europe has led to high rates of mortality and population crashes, while other populations appear to coexist alongside $B d$ with no evidence of disease (Tobler et al., 2012; Bates et al., 2018). As our understanding of the factors that influence $B d$ infection improves, it is becoming increasingly apparent that infection outcome arises from the interaction between the ecology and evolutionary history of the host (e.g. resistance and tolerance; Wilber et al., 2017), the genotype and phenotype of the fungus (e.g. infectivity and virulence; O’Hanlon et al., 2018), and the surrounding abiotic and biotic environment (e.g. environmental heterogeneity and landscape structure; Kärvemo et al., 2018). However, these factors operate across nested levels of biological organization: within-host processes underlie among-host processes within a population. Consequently, studies looking to gain insight into epidemiological processes of $B d$ must consider within-host up through population-level dynamics. Assessing environmental drivers of $B d$ disease dynamics at this scale is particularly challenging with regards to amphibian hosts, as small-scale spatial heterogeneity contributes towards the physiology of both host and pathogen. As climate acts as a proximate driver for amphibian phenology and daily activity, local climatic nuances will directly influence host activity patterns such as emergence from over-wintering habitat and onset of breeding season (Klaus \& Lougheed, 2013). These small-scale spatiotemporal 
variations may alter the local disease ecology (i.e. prevalence and intensity of infection) by facilitating or compressing opportunities for pathogen transmission and/or growth (Daversa et al., 2017, 2018). Beyond climatic patterns, anthropogenic habitat disturbance may cause a cascade of factors that exacerbate infectious disease emergence. Landscape fragmentation may alter host-pathogen dynamics by regulating host species isolation, inbreeding, and richness (Lesbarrères et al., 2006; Greer \& Collins, 2008). Thus, the nature and intensity of an amphibian-parasite interaction will be contingent upon the spatiotemporal patterns of both host and parasite (Hess et al., 2001). Despite this fact, most studies attempting to elucidate environmental drivers of $B d$ disease dynamics have focused on the spatial aspects of environmental heterogeneity alone, overlooking the importance of temporal variation (Pounds et al., 2006; Olson et al., 2013; Xie et al., 2016; however, see Clare et al., 2016). A clearer understanding of the links between environmental parameters, host breeding phenology, and the outcomes of ectothermic host-pathogen interactions will provide valuable insights into host-pathogen epidemiology, as well as more fundamental aspects of the ecology and evolution of interspecific interactions (Lambrechts et al., 2006).

Despite the presence of $B d$ within Ontario, Canada (St-Amour et al., 2008; D'Aoust-Messier et al., 2015), chytridiomycosis-driven declines are yet to be definitively reported within populations of $R$. pipiens. Yet, outside of Ontario, chytridiomycosis has been reported as the cause of mass mortality events within this species (Green et al., 2002; Voordouw et al., 2010). Consequently, Ontario populations of $R$. pipiens provide an opportunity to quantify the effect that small-scale environmental variation has on $B d$ infection parameters, in the absence of disease. We assessed adult $R$. pipiens for $B d$ infection status and quantified how prevalence (\%) and 
111 intensity of infection (genomic equivalents; GE) covaried with the following site level

112 factors: air temperature, precipitation, hydroshed size, river density, and road density.

113 In order to measure environmental variation at a scale relevant to the host,

114 temperature and precipitation were averaged across two specific time points: (1) period

115 prior to host breeding, and (2) during host breeding. Based on a priori hypotheses

116 regarding the effects of environmental factors on $B d$ disease dynamics, we hypothesize

117 that: (i) during the active period, cooler temperatures and greater precipitation will be

118 associated with increased prevalence and infection intensity in late summer (Piotrowski

119 et al., 2004; Bosch et al., 2007; Puschendorf et al., 2009), due to increased opportunities

120 for successful $B d$ transmission (Lampo et al., 2006); (ii) during the breeding period, as

121 water basins and rivers serve as likely vectors for the waterborne zoospores (Kriger \&

122 Hero, 2007), an increase in basin size will lower intensity due to diluted zoospore

123 concentrations (Briggs et al., 2010), while a reduction in river density will limit

124 transmission nodes, thus lowering prevalence and infection intensity (Sapsford et al.,

125 2013; Ruggeri et al., 2018); and (iii) increased road density will intensify landscape

126 fragmentation leading to isolated habitat patches and dense host populations, which will

127 allow for an increase in overall prevalence and intensity (Greer \& Collins, 2008;

128 Balkenhol \& Waits, 2009).

129 Materials and Methods

130 Sampling for $B d$

131 Site selection was based on the known whereabouts of $R$. pipiens populations (Fig. S1,

132 Supporting information). Sites were defined as a distinct body of water, where the

133 amphibian population was captured within a $2 \mathrm{~km}$ radius from the site centroid. All site

134 centroids were separated by a minimum of $12 \mathrm{~km}$. In total, 41 populations of $R$. pipiens

135 were surveyed for $B d$ (Fig. 1). At each site, up to 34 post-metamorphic frogs were 
136 sampled (range: 1-34, mean: 25.6; Table S1, Supporting information). In localities

137 where $R$. pipiens were rare $(\mathrm{n}<24)$, the population was sampled for 30 person-hours.

138 Each study site was geo-referenced using GPS and sampled at least once during the 139 summer months (May-August) of 2012-2014. Within the 41 sites, 14 sites were

140 identified and repeat sampled annually, during the late summer months (July-August)

141 between 2012-2014. Two of the 14 sites were sampled twice within this period, the 142 remaining 12 sites were sampled for three consecutive years. Twenty-four or more post143 metamorphic frogs were sampled at the repeat sites (range: 24-34, mean: 30.7; Table

144 S1, Supporting information). Within-site sampling occurred within a 3 week period. To 145 detect infections, we collected a toe-clip from each frog: $2-3 \mathrm{~mm}$ clip was cut from the 146 longest front toe on the left hand using sterile dissecting scissors. Toe clipping 147 facilitated identification of previously sampled individuals in subsequent years, 148 consequently no individuals were repeat sampled. Tissue samples were stored in $70 \%$ 149 ethanol at $4^{\circ} \mathrm{C}$ until processing (Hyatt et al., 2007). Standardized protocols and 150 biosecurity measures were followed to prevent pathogen transmission (Phillott et al., 151 2010). Snout-vent length (SVL) was measured to the nearest $0.01 \mathrm{~mm}$. We 152 distinguished between three life history stages: recent metamorphs ( $\mathrm{SVL}<45 \mathrm{~mm}$ ), 153 juveniles (SVL: 45-52 mm) and adults (SVL > $52 \mathrm{~mm}$; Wright \& Wright, 1949). When 154 modelling the effect of spatiotemporal environmental heterogeneity on late summer 155 infection parameters, we excluded metamorphs from the analysis as natal dispersal and 156 behaviour is dissimilar to that observed in juveniles and adults (Dole, 1965). DNA was 157 extracted using DNeasy Blood and Tissue kit (Qiagen) according to the manufacturer's 158 instructions. Presence/absence and quantity of $B d$ was then assessed using the 159 quantitative PCR (qPCR) protocol described by Boyle et al. (2004). To avoid inhibition, 160 all extractions were diluted $1 / 10$ prior to qPCR, therefore results were multiplied by 10 
161 in order to determine the true value. All samples were run in duplicate, and a sample 162 was considered $B d$ positive if both wells amplified and an average estimate of $0.1 \mathrm{GE}$

163 or above was produced when comparing the sample to the curve generated by the

164 standards $(1000,100,1$ and 0.1$)$.

165 Acquisition of environmental data with respect to host life history

166 The emergence of $R$. pipiens from overwintering sites is triggered by the onset of 167 spring, specifically the first day on which the mean daytime temperature exceeded zero 168 degrees Celsius for fourteen consecutive days. Frogs then become terrestrially active, 169 travelling up to $1.6 \mathrm{~km}$ to their breeding ponds (Kendell, 2003). Breeding period 170 commences when male frogs start calling. This occurs when the daytime air 171 temperature persistently averages $15^{\circ} \mathrm{C}$ (Seburn, 1992). Both sexes exhibit strong site 172 fidelity and limited movement during the breeding period (Waye \& Cooper, 2000). As

173 far as we are aware, there are no quantitative estimates regarding the end of the breeding

174 period for $R$. pipiens within Ontario. Consequently, based on a priori knowledge 175 regarding breeding periods for $R$. pipiens across Canada, we subjectively defined the 176 end of the breeding period as the last day of June (Harding, 1997; Stebbins, 2003;

177 Government of Canada, 2009; Voordouw et al., 2010). For the purposes of this study, 178 the period between spring emergence and calling will henceforth be referred to as the

179 'active period', and the period between calling and the end of the breeding period will

180 henceforth be referred to as the 'breeding period'. As these two periods are 181 differentiated by host phenology and local climatic nuances, we wished to record spatial 182 heterogeneities during the two-time periods. Consequently, we collected data on the 183 following: length of active period, air temperature during active period and breeding 184 period, precipitation during active period and breeding period, hydroshed area, river 185 density and road density. 
187 Pro v2 Data Logger (U23-001)) activated at 10 sites and weather stations in close 188 proximity to 22 sites (Fig. 1 and Table S1, Supporting information). Any gaps in the

189 hourly records were replaced with data from the second closest weather station (range:

190 1.4-44.69 km, mean: $17.4 \mathrm{~km}$; Government of Canada, 2015a). This dataset allowed

191 for the estimation of the following annual variables: 'spring onset', 'calling date',

192 'active period': period between spring onset and calling date; and 'breeding period':

193 period between the calling date and the last day of June. Each site locality was assigned

194 to a drainage basin, downloaded from USGS HydroSHEDS (Lehner et al., 2008). Mean

195 monthly precipitation was obtained as environmental layers downloaded from the

196 WorldClim data set (version 1.4; Hijmans et al., 2005). Both variables were re-

197 projected and re-sampled to the same equal area grid as the site localities. Hydroshed 198 area $\left(\mathrm{km}^{2}\right)$ and mean monthly precipitation $(\mathrm{mm})$ during both the 'active period' and

199 'breeding period' were obtained by extracting the raw value of each variable at all site

200 localities from their raster source. Temperature and precipitation data for 9 sites were 201 not compiled, as only $2 \%$ of total individuals were located within these sites (Table S1, 202 Supporting information).

203 River and road cartographic boundary files were obtained from the Statistics 204 Canada census (Statistics Canada, 2011) and the National Road Network for Ontario 205 Geobase (Government of Canada, 2015b), respectively. The density of rivers and roads 206 surrounding each site locality was obtained by calculating the extent to which each 207 spatial line dataframe overlapped a cell within a spatially explicit blank raster, and 208 subsequently extracting the mean value of all raster cells found in a radius of $10 \mathrm{~km}$ 209 and $50 \mathrm{~km}$ around each site locality, respectively. The apportioned radius for 210 calculating road density was increased from $10 \mathrm{~km}$ to $50 \mathrm{~km}$, in order to include 
211 maximum variation recorded in the dataset, with regards to habitat fragmentation and

212 local disturbance. Details regarding the variations (per grid cell), raw resolutions, year

213 of record, unit and source for all spatial predictors are listed in Table S2 (Supporting

214 information).

\section{Statistical analyses}

216 All statistical analyses were implemented in R (version 3.1.2; R Core Team, 2015).

217 Linear regression was carried out to assess the relationship between length of active 218 period (days), spring onset (decimal date), calling date (decimal date), and year.

219 Presence of infection was compared between sites using a Fisher's exact test for count 220 data. Variation in prevalence and infection intensity (rounded to whole numbers and 221 treated as count data) were compared between sites, years, and development status 222 (adult/juvenile) with $\chi^{2}$ tests and univariate ANOVA, respectively. Any significant 223 results from ANOVA testing were further tested using Tukey post hoc tests in order to 224 determine which categorical groupings were different from the others. We included 225 data from all 41 sites in the above tests in order to increase precision of estimates. 226 However, in order to disentangle spatial from temporal effects over the 3 year period, 227 the following modelling exercise was restricted to 14 sites visited at least twice, during 228 the late summer months (July-August) between 2012-2014 inclusive, with at least 24 229 frogs sampled per year (Fig. 1 and Table S1, Supporting information). Two separate 230 generalized linear mixed models (GLMMs) were constructed, implementing a 231 Binomial error structure for the $B d$ prevalence model and a Negative Binomial error 232 structure to the $B d$ intensity of infection model (mean GE). We accounted for possible 233 non-independence of samples collected at the same site locality by including a random 234 intercept effect for site ID ( $\mathrm{n}=14)$ and added year as a fixed effect. We did not expect 235 serial autocorrelation to be present in the data as sampling occurred once per year. 
236 Excluding all models that included confounding pairs of covariates (absolute 237 correlation coefficient $>0.5$ ), we constructed a set of 31 competing candidate models 238 to test against $B d$ prevalence (Table S3, Supporting information) and $B d$ intensity of 239 infection, separately (Table S4, Supporting information). Predictor variables included: 240 length of active period (days), mean daily air temperature $\left({ }^{\circ} \mathrm{C}\right)$ throughout active period, 241 mean daily air temperature $\left({ }^{\circ} \mathrm{C}\right)$ throughout breeding period, mean precipitation $(\mathrm{mm})$ 242 throughout active period, mean precipitation $(\mathrm{mm})$ throughout breeding period, 243 hydroshed area $\left(\mathrm{km}^{2}\right)$, river density (within $10 \mathrm{~km}$ buffer from site centroid) and road 244 density (within $50 \mathrm{~km}$ buffer from site centroid). All variables were z-transformed [(x245 mean)/SD] prior to analysis to have a mean of 0 and standard deviation of 1 , putting 246 all predictors on a common scale, and making main effects interpretable in the presence 247 of interactions. We used an information-theoretic approach to identify the model(s) 248 with the strongest support in the data. Specifically, we used Akaike's information 249 criterion (AIC) to select among the intensity of infection models, and quasi-AIC 250 (QAIC) for $B d$ prevalence models in order to correct for overdispersion (c-hat=6.45; 251 Burnham \& Anderson, 2002). We used a delta-6 information criterion cut off for the 252 top model set, where all models within 6 points of the model with the best support in 253 the data (lowest IC score) were considered to have roughly equivalent support (Harrison 254 et al., 2018). Furthermore, we applied the 'nesting rule', in which models that are more 255 complex versions of models with better support (lower AIC) are removed from the top 256 model set (Richards et al., 2011; Harrison et al., 2018). Remaining models were 257 selected for model averaging. We present model-averaged predictions from these 258 models alongside predictions from the top model. Predicted means and 95\% credible 259 intervals were extracted based on 1000 simulations (Gelman \& Hill, 2007).

\section{$260 \quad$ Results}


261 We collected 2223 toe clips from post-metamorphic $R$. pipiens, captured from 41 sites 262 in Ontario. Of the 2223 R. pipiens sampled, 833 were sampled in 2012, 878 were 263 sampled in 2013, and 512 were sampled in 2014. Overall prevalence was $28.9 \%$. 264 Infection was detected across a broad geographic range (36 of 41 sites were infected; 265 Fig. 1) and despite presence of strong infections (maximum GE = 7427.23, Table S1, 266 Supporting information) no mortality or moribund individuals were observed. We 267 sampled 1229 R. pipiens within the 14 repeat sampled sites; $75 \%$ of individuals were 268 sampled post breeding period, while the remaining $25 \%$ were sampled within 10 days 269 of the final day of the breeding period. $B d$ prevalence (\%) and intensity of infection (GE) did not vary between adults 271 and juveniles. However, both infection metrics varied significantly between years. 272 Prevalence in 2013 was significantly higher than 2012 and $2014\left(\chi^{2}=69.7, p<0.0001\right.$, $273 \mathrm{df}=1 ; \chi^{2}=149.2, \mathrm{p}<0.0001, \mathrm{df}=1$, respectively). We recorded a $79.8 \%$ increase in 274 prevalence between 2012 and 2013, and a 73.1\% decrease in prevalence between 2013 275 and 2014 (Fig. S2, Supporting information). Infection intensity (GE) was also greatest 276 in 2013 (mean GE $[\mathrm{SE}]=138.8[19.1]$, maximum $\mathrm{GE}=7427.2, \mathrm{~F}_{2,2220}=32.8, \mathrm{p}<$ 2770.0001 ) than 2012 (mean GE $[\mathrm{SE}]=16.9$ [4.4], maximum GE $=2708.3 ; \mathrm{p}<0.0001$ ) or $2782014($ mean GE $[\mathrm{SE}]=2.7[0.8]$, maximum GE $=312.3 ; \mathrm{p}<0.0001 ;$ Fig. S3, Supporting 279 information). Sites repeat sampled in 2012 and 2013 showed variation in prevalence $280\left(\chi^{2}=255.2, \mathrm{p}<0.001, \mathrm{df}=13 ; \chi^{2}=165.3, \mathrm{p}<0.001, \mathrm{df}=13\right.$, respectively $)$ and infection 281 intensity $\left(\mathrm{F}_{33,799}=2.7, \mathrm{p}<0.001 ; \mathrm{F}_{33,842}=7.3, \mathrm{p}<0.0001\right)$. However, neither prevalence 282 nor intensity varied between sites in 2014 , as both infection measures remain 283 consistently low (Fig. 2).

284 Frogs experienced cooler temperatures during their active period in 2013 in 285 comparison to $2012\left(\mathrm{~F}_{1,77}=7.9, \mathrm{p}<0.01\right)$, but no other among-year comparisons were 
significant (Table 1). Frogs also experienced cooler temperatures during their breeding period in 2013 in comparison to $2012\left(\mathrm{~F}_{1,77}=8.4, \mathrm{p}<0.01\right)$ and $2014\left(\mathrm{~F}_{1,77}=26.9, \mathrm{p}<\right.$ 0.0001; Table 1). Mean precipitation throughout the active or breeding period did not differ between years (Table 1). Decimal date for both spring onset and calling date differed significantly between years $\left(\mathrm{F}_{4,160}=50.0, \mathrm{p}<0.0001 ; \mathrm{F}_{4,160}=14.1, \mathrm{p}<0.0001\right.$, respectively) with 2012 exhibiting earlier dates than any other year (Table 2). There was a shift towards a later spring date, with an average delay of 0.21 days 293 per annum $(\mathrm{t}=3.79, \mathrm{p}<0.001$; Table 3$)$, and an earlier calling date, with the 294 advancement of 5.13 days per annum $(t=-2.45, \mathrm{p}<0.05$; Table 3). Despite observing 295 a 27.85 day delay between the 2012 and 2013 spring onset, the 2013 calling date was 296 delayed by a mere 3.97 days. Correspondingly, the length of active period differed 297 significantly between years $\left(\mathrm{F}_{4,160}=15.9, \mathrm{p}<0.0001\right)$ with 2013 exhibiting a shorter 298 active period than all other years. On average, there was a shift towards a shorter active 299 period, with an average reduction of 5.33 days per annum $(\mathrm{t}=-4.89, \mathrm{p}<0.001$; Table $3003)$.

\section{$301 \quad$ Factors predicting $\boldsymbol{B} \boldsymbol{d}$ prevalence in late summer}

302 Restricting the model to the 14 repeat sampled sites, the model predicting $B d$ 303 prevalence, with the highest support in the data, comprised of an interaction between 304 mean daily air temperature during active period and length of active period. After 305 applying the nesting rule, there were four models in the delta-6 QAIC candidate set 306 (Table S3, Supporting information, see Table 4 for model-averaged estimates). $B d$ 307 prevalence was negatively correlated with mean daily air temperature during active 308 period, while prevalence increased as the length of active period was extended (Fig. 3). 309 More specifically, as length of active period increased, the negative relationship 310 between $B d$ prevalence and mean daily air temperature weakened, while the variation 
311 in $B d$ prevalence remained relatively constant throughout the range of temperatures.

312 Conversely, as length of active period shortened, the negative effect of mean daily air

313 temperature on $B d$ prevalence strengthened (larger negative slope), while variation in

$314 B d$ prevelance fluctuated dependent on temperature. The highest prevalence outcome

315 was predicted to occur when the active period was shortened and when mean air

316 temperature was coolest.

\section{Factors predicting $\boldsymbol{B} \boldsymbol{d}$ intensity in late summer}

318 Models predicting intensity of infection, were generated using the 14 repeat sampled

319 sites. There were three models in the delta-6 AIC candidate set after applying the

320 nesting rule (Table S4, Supporting information, see Table 4 for model-averaged

321 estimates). The best-supported model included hydroshed area, and an interaction

322 between river density and mean precipitation throughout breeding period. Intensity of

323 infection (mean GE) was negatively correlated with hydroshed area (Fig. 4), but

324 positively correlated with both river density and mean precipitation throughout

325 breeding period (Fig. 5). As river density increased, the positive relationship between

326 infection intensity and mean precipitation during breeding period became significantly

327 stronger (larger positive slope). As both predictor variables increased, infection

328 intensity grew exponentially. Within site localites with low surrounding river densites,

329 mean infection intensity only increased when precipitation levels were low.

\section{Discussion}

331 Our results highlight that spatial variation in pathogen prevalence and infection

332 intensity at the landscape scale is driven by the covariation between host behaviour and

333 local environmental conditions. Within sites, strong prevalence and intensity of $B d$

334 infection in late summer emerged when previous temperatures were low, rainfall was 
335 high, hydrosheds were small, and river networks were dense. This suggests that 336 interannual variation of local climatic regimes interact with stable geographic factors 337 (such as hydrology), to inhibit the build-up of $B d$ infection intensity and prevalence. 338 More specifically, our analyses show evidence for: (1) the existence of both spatial and 339 temporal heterogeneity in infection among sites; (2) evidence for a relationship between $340 B d$ prevalence and thermal regimes prior to host breeding at the site level; (3) evidence 341 for a relationship between infection intensity and aquatic conditions throughout host 342 breeding period at the site level; and (4) no evidence for a relationship between $B d$ 343 prevalence/ infection intensity, and road density. Furthermore, despite the fact that 344 studies may predict implicit deterministic relationships between $B d$ prevalence and 345 infection intensity, these infection parameters are governed, at least in part, by different 346 environmental factors operating during separate life history events. This emphasizes 347 the importance of measuring both infection parameters within a spatiotemporal context, 348 when attempting to gain insight into $B d$ infection dynamics.

349 Once $R$. pipiens emerge from their overwintering sites, local climatic conditions 350 may determine whether $B d$ is able to establish within a population. Localities that 351 experienced short warm climates prior to breeding were unlikely to support the 352 establishment of $B d$, while sites that experienced cold temperatures, irrespective of 353 duration, were most likely to harbour $B d$ infections in late summer. These results 354 support both bioclimatic predictive models (Ron, 2005; Puschendorf et al., 2009) and 355 laboratory studies (Longcore et al., 1999; Johnson et al., 2003) that point to $B d$ being 356 favoured by cooler temperatures. However, the temperatures experienced during the 357 active period are well below lab-based estimates of the optimal thermal range for fungal 358 growth $\left(17-25^{\circ} \mathrm{C}\right.$; Longcore et al., 1999; Johnson et al., 2003). Woodhams et al. (2008) 359 identified that at lower temperatures growth rate slows, but fecundity and the life span 
360 of the zoospore increase, which should influence probability of infection. This is 361 consistent with our observations of higher prevalence in populations experiencing 362 cooler climates.

363 Our climate analyses provide evidence for the shortening of active period by 3645.33 days per annum or 21.33 days over the four-year period. As $B d$ prevalence is 365 predicted to decrease as the length of active period decreases, it would seem reasonable 366 to suggest this annual curtailment may lower the infection risk faced by $R$. pipiens 367 populations. Conversely, 2013 presented the shortest active period and the highest $B d$ 368 prevalence. Frogs sampled in 2013 also experienced the coolest mean temperatures 369 during the active period. This highlights the importance of the interaction between the 370 two variables. The extension or shortening of the active period has little effect on $B d$ 371 prevalence when mean temperatures are low (between $5-8^{\circ} \mathrm{C}$ ). Extending this period 372 when temperatures are warm $\left(10-12^{\circ} \mathrm{C}\right)$, generates an increase in prevalence, while 373 limiting this period leads to a reduction in prevalence. We suggest that this pattern may 374 be due to expanded opportunities for the successful transmission of $B d$ between 375 individuals when the active period is elongated and warmer.

376 All variables that correlate with $B d$ mean intensity are emergent properties of 377 site hydrology: hydroshed area, surrounding river density, and mean precipitation 378 throughout the breeding period. This corroborates predictions that $B d$ should be more 379 abundant in wetter areas (Ron, 2005; Kriger et al., 2007), and field studies indicating 380 that $B d$ outbreaks might be more likely under wet conditions (Lips et al., 2006; Bosch 381 et al., 2007). Yet, no published study has linked infection intensity with a reduction in 382 either (1) the size of water basin (hydroshed area), or (2) the density of river networks 383 (however, see Spitzen-van der Sluijs et al., 2017; Kärvemo et al., 2018). We found that 384 as hydroshed area increased, infection intensity decreased slightly, suggesting that $R$. 
pipiens populations concentrated within a small drainage basin may facilitate the proliferation and transmission of zoospores, as increasing host population density increases transmission rates (Briggs et al., 2010). Additionally, larger hydrosheds may allow for greater dilution of zoospores, and thus the frequency with which a zoospore

389 interacts with a host may decrease with increasing spatial context. However, the 390 predicted effect of hydroshed area on mean $B d$ intensity (predicted $B d$ mean intensity 391 range: 0-20 GE) is significantly weaker than the predicted effect of the complex 392 interaction (river density and mean precipitation) on mean $B d$ intensity (predicted $B d$ 393 mean intensity range: 0-500 GE). Mean infection intensity is predicted to increase 394 exponentially when precipitation levels during the breeding period are high, and when 395 frogs are located at sites containing dense river concentrations. When precipitation 396 levels are low during the breeding period, high river density sites will elicit no variation 397 from the global mean, while sites surrounded by very few rivers will experience a small 398 increase in mean infection intensity. There are two hypotheses that can explain these 399 patterns. First, rivers serve as likely vectors for the waterborne zoospores of $B d$ (Kriger $400 \&$ Hero, 2007). A high concentration of rivers within a $10 \mathrm{~km}^{2}$ area suggests an increase 401 in transmission channels via aquatic nodes, or feasible amphibian movement between 402 catchments. The connectivity of river networks may prove particularly influential as 403 zoospores may be carried away with water currents, thus expanding the spatial reach of 404 infection. When precipitation levels are high, moisture levels will be elevated within 405 the terrestrial environment, along with the aquatic, which increase zoospore movement, 406 survival and colonization (Piotrowski et al., 2004). This is especially important for this 407 host-pathogen interaction, as $R$. pipiens is a semi-terrestrial anuran. Consequently, 408 when individuals are active within the terrestrial realm, increased moisture from heavy 409 rainfall facilitates reinfection from zoospores released within the skin and onto the skin 
410 surface, in turn aiding the significant increase in infection intensity (Daversa et al.,

411 2018). Alternatively, weak precipitation levels lead to dryer environments, especially

412 when rivers are not well connected. This may force individuals to congregate in smaller

413 pools, thus increasing opportunity for successful $B d$ transmission. However, zoospore

414 growth will also be constrained during this period, due to limited moisture availability

415 within the terrestrial realm (Johnson et al., 2003, Daversa et al., 2018). The shared

416 theme in these two hypotheses is the role of re-infection. We suggest that the increase

417 in strength of infection in the system is largely attributable to within-host reinfection

418 (from zoospores released within the skin and onto the skin surface) rather than among-

419 host transmission.

420 Akin to other ectotherms, the health of amphibians is sensitive to changes in

421 ambient temperatures (Raffel et al., 2006). Despite this, the role of climate change in

422 the unprecedented decline of ectothermic biodiversity and emergence of infectious

423 diseases remains controversial (Rohr et al., 2011). Impacts of climate change on host-

424 pathogen dynamics are expected to be particularly strong for ectotherms, as host

425 metabolism and activity patterns are closely linked to environmental temperatures,

426 which in turn, directly influence the establishment of the pathogen. Less attention has

427 been devoted to the consequences of changes in precipitation and water availability. A

428 strong impact is expected for host and pathogen, as both species rely on humid

429 environments, require water for reproduction, and are particularly active during wet

430 periods. It is imperative that we trace activity patterns and assess the environment in

431 which these infection dynamics operate, as the value of predictive modelling for

432 infection risk increases substantially when parameters affecting local host species-

433 specific infection dynamics are considered at a local scale (Paaijmans et al., 2009).

434 However, with the current absence of quantitative summaries across multiple studies, 
435 it is difficult to identify general patterns. These results of differential, context436 dependent host susceptibility to $B d$ is supported by Doddington et al., (2013) and may 437 be a pattern exhibited by other fungal pathogens that threaten wildlife hosts (Fisher et 438 al., 2012). This observation highlights a crucial need for long-term ecological studies 439 that examine the consequences of climate-disease interactions within local 440 communities, as changing environmental conditions could shift the balance from co441 existence to significant mortality in some populations, but not in others. This 442 knowledge will directly affect the framing and development of conservation efforts to 443 mitigate infections. Furthermore, studying the patterns of local infections may be 444 crucial to understanding how infection dynamics affect biodiversity at larger spatial 445 scales. Hence, we stress the exigency to identify how local factors may exacerbate or 446 reduce the impact of an infectious disease.

\section{Acknowledgments}

448 We would like to thank A. M. D'Aoust-Messier, B. Grainger-Wood, A. Colles, S. S.

449 Cruickshank and B. J. Varela for assisting with field work and logistics. Field surveys 450 and specimen collection were conducted under the Ontario Ministry of Natural 451 Resources Wildlife Scientific Collector's Authorization (\#1068178). Amphibian 452 sampling within protected areas followed permit guidelines awarded by: Parks Canada 453 Agency (\#BPF-2013-13913); Ontario Ministry of Natural Resources and Forestry 454 (\#4534); Nature Conservancy of Canada (\#AG-ON-2012-144055); and St. Clair 455 Region Conservation Authority (\#SCRCA-2012-28-05). TWJG and KMM were 456 supported by NERC (NE/G002193/1) and KMM by the Ontario Trillium Scholarship.

\section{$\underline{\text { Authors' contributions }}$}


458 KMM conceived the ideas and designed methodology; KMM collected the data; KMM 459 and XAH analysed the data; KMM led the writing of the manuscript. All authors 460 contributed critically to the drafts and gave final approval for publication.

\section{$461 \quad$ Data availability}

462 Data are available from the Figshare repository:

463 https://figshare.com/account/home\#/projects/71426 (McMillan et al., 2019). 


\section{$\underline{\text { References }}$}

Altizer, S., Otsfeld, R. S., Johnson, P. T., Kutz, S., \& Harvell, C. D. (2013). Climate change and infectious diseases: from evidence to a predictive framework. Science, 341(6145), 514-519. doi: 10.1126/science.1239401

Balkenhol, N., \& Waits, L. P. (2009). Molecular road ecology: exploring the potential of genetics for investigating transportation impacts on wildlife. Molecular Ecology, 18(20), 4151-4164. doi: 10.1111/j.1365-294X.2009.04322.x

Bates, K. A., Clare, F. C., O'Hanlon, S., Bosch, J., Brookes, L., Hopkins, K., ... Harrison, X. A. (2018). Amphibian chytridiomycosis outbreak dynamics are linked with host skin bacterial community structure. Nature Communications, 9(693). doi: 10.1038/s41467-018-02967-w

Bosch, J., Carrascal, L. M., Duran, L., Walker, S., \& Fisher, M. C. (2007). Climate change and outbreaks of amphibian chytridiomycosis in a montane area of Central Spain; is there a link? Proceedings of the Royal Society B: Biological Sciences, 274(1607), 253-260. doi: 10.1098/rspb.2006.3713

Boyle, D. G., Boyle, D. B., Olsen, V., Morgan, J. A. T., \& Hyatt, A. D. (2004). Rapid quantitative detection of chytridiomycosis (Batrachochytrium dendrobatidis) in amphibian samples using real-time Taqman PCR assay. Diseases of Aquatic Organisms, 60(2), 141-148. doi: 10.3354/dao060141

Briggs, C. J., Knapp, R. A., \& Vredenburg, V. T. (2010). Enzootic and epizootic dynamics of the chytrid fungus pathogen of amphibians. Proceedings of the National Academy of Sciences of the USA, 107(21), 9695-9700. doi: 10.1073/pnas.0912886107 Burnham, K. P., \& Anderson, D. R. (2002). Model selection and multimodel inference: a practical information-theoretic approach (2nd ed.). Springer-Verlag, New York. 
488 Clare, F. C., Halder, J. B., Daniel, O., Bielby, J., Semenov, M. A., Jombart, T., 489 ...Fisher, M. C. (2016). Climate forcing of an emerging pathogenic fungus across a 490 montane multi-host community. Philosophical Transactions of the Royal Society, $491 \quad$ B371, 20150454. doi:10.1098/rstb.2015.0454

492 D'Aoust-Messier, A. M., Echaubard, P., Billy, V., \& Lesbarrères, D. (2015). 493 Amphibian pathogens at northern latitudes: presence of chytrid fungus and ranavirus in 494 northeastern Canada. Diseases of Aquatic Organisms, 113(2), 149-155. doi: $495 \quad 10.3354 /$ dao02837

496 Daversa, D. R., Manica, A., Bosch, J., Jolles, W. J., \& Garner, T.W.J. (2018). Routine 497 habitat switching alters the likelihood and persistence of infection with a pathogenic 498 parasite. Functional Ecology, 32(5), 1262-1270. doi: 10.17863/CAM.20593

499 Daversa, D. R., Fenton, A., Dell, A. I., Garner, T.W.J., \& Manica, A. (2017). Infections 500 on the move: how transient phases of host movement influence disease spread. 501 Proceedings of the Royal Society of London. Series B: Biological Sciences, 284(1869), 502 20171807. doi: 10.1098/rspb.2017.1807

503 Doddington, B. J., Bosch, J., Oliver, J. A., Grassly, N. C., Garcia, G., Schmidt, B. R., 504 ... Fisher, M. C. (2013). Context-dependent amphibian host population response to an 505 invading pathogen. Ecology, 94(8), 1795-1804. doi: 10.1890/12-1270.1

506 Dole, J. W. (1965). Spatial relations in natural populations of the leopard frog, Rana 507 pipiens Schreber, in northern Michigan. American Midland Naturalist, 74(2), 464-478. 508 doi: $10.2307 / 2423276$

509 Fisher, M. C., Henk, D. A., Briggs, C. J., Brownstein, J. S., Madoff, L. C., McCraw, S. 510 L., \& Gurr, S. J. (2012). Emerging fungal threats to animal, plant and ecosystem health. 511 Nature, 484(7393), 186-194. doi: 10.1038/nature10947 
512 Gelman, A., \& Hill, J. (2007). Data analysis using regression and multilevel/

513 hierarchical models. Cambridge University Press.

514 Government of Canada (2015a). Historical Data. Available:

515 http://climate.weather.gc.ca/historical_data/search_historic_data_e.html [accessed: 5162015 June 10].

517 Government of Canada (2015b). National Road Network (NRN) - Ontario. Available: 518 https://open.canada.ca/data/en/dataset/3d282116-e556-400c-9306-ca1a3cada77f 519 [accessed: 2015 June 10].

520 Government of Canada (2009). Species Profile: Northern Leopard Frog Western 521 Boreal/Prairie populations. Available: https://wildlife-species.canada.ca/species-risk522 registry/species/speciesDetails_e.cfm?sid=552 [accessed 2013 January 12].

523 Green, D. E., Converse, K. A., \& Schrader, A. K. (2002). Epizootiology of sixty-four 524 amphibian mortality and morbidity events in the USA, 1996 - 2001. Annals of the New 525 York Academy of Sciences, 969(1), 323-339. doi: 10.1111/j.1749$526 \quad 6632.2002 . t b 04400 . x$

527 Greer, A. L., \& Collins, J. P. (2008). Habitat fragmentation as a result of biotic and 528 abiotic factors controls pathogen transmission throughout a host population. Journal of 529 Animal Ecology, 77(2), 364-369. doi: 10.1111/j.1365-2656.2007.01330.x

530 Harding, J. H. (1997). Amphibians and reptiles of the Great Lakes Region. University 531 of Michigan Press, Ann Arbor, Michigan, USA.

532 Harrison, X. A., Donaldson, L., Correa-Cano, M. E., Evans, J., Fisher, D. N., Goodwin, 533 C., ... Inger, R. (2018). A brief introduction to mixed effects modelling and multi534 model inference in ecology. PeerJ, 6, e4794. doi:10.7717/peerj.4794 
535 Hess, G. R., Randolph, S. E., Arneberg, P., Chemini, C., Furlanello, C., Harwood, J., 536 ... Swinton, J. (2001). Spatial aspects of disease dynamics. In P. J. Hudson, A. Rizzoli, 537 B. T. Grenfell, H. Heesterbeek \& A. P. Dobson (Eds.), The ecology of wildlife diseases 538 (pp. 102-118). Oxford, UK: Oxford University Press.

539 Hijmans, R. J., Cameron, S. E., Parra, J. L., Jones, P. G., \& Jarvis, A. (2005). Very high 540 resolution interpolated climate surfaces for global land areas. International Journal of 541 Climatology, 25(15), 1965-1978. doi: 10.1002/joc.1276

542 Hyatt, A. D., Boyle, D. G., Olsen, V., Boyle, D. B., Berger, L., Obendorf, D., ... 543 Colling, A. (2007). Diagnostic assays and sampling protocols for the detection of 544 Batrachochytrium dendrobatidis. Diseases of Aquatic Organisms, 73(3), 175-192. doi: $545 \quad 10.3354 /$ dao073175

546 Johnson, M. L., Berger, L., Philips, L. \& Speare, R. (2003). Fungicidal effects of 547 chemical disinfectants, UV light, desiccation and heat on the amphibian chytrid 548 Batrachochytrium dendrobatidis. Disease of Aquatic Organisms, 57(3): 255-260. doi: $549 \quad 10.3354 /$ dao057255

550 Kärvemo, S., Meurling, S., Berger, D., Höglung, J., \& Laurila, A. (2018). Effects of 551 host species and environmental factors on the prevalence of Batrachochytrium 552 dendrobatidis in northern Europe. PLoS ONE, 13(10), e0199852. 553 doi: 10.1371/journal.pone.0199852

554 Kendell, K. (2003). Status of the northern leopard frog (Rana pipiens) in Alberta: 555 update 2003. Alberta Sustainable Resource Development, Fish and Wildlife Division, 556 and Alberta Conservation Association, Wildlife Status Report, (9). 
557 Klaus, S. P., \& Lougheed, S. C. (2013). Changes in breeding phenology of eastern 558 Ontario frogs over four decades. Ecology and Evolution, 3(4), 835-845. 559 doi: $10.1002 /$ ece 3.501

560 Kriger, K. M., \& Hero, J. M. (2007). The chytrid fungus Batrachochytrium 561 dendrobatidis is non-randomly distributed across amphibian breeding habitats. 562 Diversity and Distributions, 13(6), 781-788. doi: 10.1111/j.1472-4642.2007.00394.x

563 Kriger, K. M., Pereoglou, F., \& Hero, M. (2007). Latitudinal variation in the prevalence 564 and intensity of chytrid (Batrachochytrium dendrobatidis) infection in eastern 565 Australia. Conservation Biology, 21(5), 1280-1290. doi: 10.1111/j.1523$566 \quad 1739.2007 .00777 . x$

567 Lambrechts L., Chavatte J. -M., Snounou G., \& Koella J. C. (2006). Environmental 568 influence on the genetic basis of mosquito resistance to malaria parasites. Proceedings 569 of the Royal Society of London. Series B: Biological Sciences, 273(1593), 1501-1506. 570 doi: $10.1098 / \mathrm{rspb} .2006 .3483$

571 Lampo, M., Rodriguez-Contreras, A., La Marca, E., \& Daszak, P. (2006). A 572 chytridiomycosis epidemic and a severe dry season precede the disappearance of 573 Atelopus species from the Venezuelan Andes. Herpetological Journal, 16(14), 395-402.

574 Lehner, B., Verdin, K., \& Jarvis, A. (2008). New global hydrography derived from 575 spaceborne elevation data. Eos, Transactions American Geophysical Union, 89(10), 93576 94. doi: 10.1029/2008EO100001

577 Lesbarrères, D., Primmer, C. R., Lodé, T., \& Merilä, J. (2006). The effects of 20 years 578 of highway presence on the genetic structure of Rana dalmatina populations. 579 Ecoscience, $\quad$ 13(4), $531-538 . \quad$ doi: $580 \quad 6860(2006) 13[531:$ TEOYOH $] 2.0 . \mathrm{CO} ; 2$ 
581 Lips, K. R., Brem, F., Brenes, R., Reeve, J. D., Alford, R. A., Voyles, J., ... Collins, J. 582 P. (2006). Emerging infectious disease and the loss of biodiversity in a Neotropical 583 amphibian community. Proceedings of the National Academy of Sciences of the USA, 584 103(9), 3165-3170. doi: 10.1073/pnas.0506889103

585 Longcore, J., Pessier, A., \& Nichols, D. (1999). Batrachochytrium dendrobatidis gen. 586 et sp. nov., a chytrid pathogenic to amphibians. Mycologia, 91(2), 219-227. doi: $587 \quad 10.2307 / 3761366$

588 McMillan, K. M., Lesbarrères, D., Harrison, X. A., \& Garner, T. W. J. (2019). Data 589 from: Spatiotemporal heterogeneity decouples infection parameters of amphibian 590 chytridiomycosis. Figshare, https://figshare.com/account/home\#/projects/71426

591 O’Hanlon, S. J., Rieux, A., Farrer, R. A., Rosa, G. M., Waldman, B., Bataille, A., ... 592 Fisher, M. C. (2018). Recent Asian origin of chytrid fungi causing global amphibian 593 declines. Science, 360(6389), 621-627. doi: 10.1126/science.aar1965

594 Olson, D. H., Aanensen, D. M., Ronnenberg, K. L., Powell, C. I., Walker, S. F., Bielby, 595 J., ... Weaver, G., The Bd Mapping Group \& Fisher, M. C. (2013). Mapping the global 596 emergence of Batrachochytrium dendrobatidis, the amphibian chytrid fungus. PLoS 597 ONE, 8(2), e56802. doi: 10.1371/journal.pone.0056802

598 Ostfeld, R. S., Glass, G. E., \& Keesing, F. (2005). Spatial epidemiology: an emerging 599 (or re-emerging) discipline. Trends in Ecology and Evolution, 20(6), 328-336. doi: $600 \quad 10.1016 /$ j.tree.2005.03.009

601 Paaijmans, K. P., Read, A. F., \& Thomas, M. B. (2009). Understanding the link between 602 malaria risk and climate. Proceedings of the National Academy of Sciences of the USA, 603 106(33), 13844-13849. doi: 10.1073/pnas.0903423106 
604 Phillott, A. D., Speare, R., Hines, H. B., Skerratt, L. F., Meyer, E., McDonald, K. R., 605 ... Berger, L. (2010). Minimising exposure of amphibians to pathogens during field 606 studies. Diseases of Aquatic Organisms, 92(2-3), 175-185. doi: 10.3354/dao02162

607 Piotrowski, J. S., Annis, S. L., \& Longcore, J. E. (2004). Physiology of 608 Batrachochytrium dendrobatidis, a chytrid pathogen of amphibians. Mycologia, 96(1), 609 9-15. doi: $10.2307 / 3761981$

610 Pounds, J. A., Bustamante, M. R., Coloma, L. A., Consuegra, J. A., Fogden, M. P. L., 611 Foster, P. N., ... Young, B. E. (2006). Widespread amphibian extinctions from 612 epidemic disease driven by global warming. Nature, 439(7073), 161-167. doi: $61310.1038 /$ nature04246

614 Puschendorf, R., Carnaval, A. C., VanDerWal, J., Zumbado-Ulate, H., Chaves, G., 615 Bolaños, F., \& Alford, R. A. (2009). Distribution models for the amphibian chytrid 616 Batrachochytrium dendrobatidis in Costa Rica: proposing climatic refuges as a 617 conservation tool. Diversity and Distributions, 15(13), 401-408. doi: 10.1111/j.1472$618 \quad 4642.2008 .00548 . x$

619 R Core Team (2015). R: A language and environment for statistical computing: R 620 Foundation for Statistical Computing. Vienna, Austria, 3(0). Available: http://www.r621 project.org/ [accessed 2012 January 5].

622 Raffel, T. R., Rohr, J. R., Kiesecker, J. M., \& Hudson, P. J. (2006). Negative effects of 623 changing temperature on amphibian immunity under field conditions. Functional 624 Ecology, 20(5), 819-828. doi: 10.1111/j.1365-2435.2006.01159.x

625 Richards, S. A., Whittingham, M. J., \& Stephens, P. A. (2011). Model selection and 626 model averaging in behavioural ecology: the utility of the IT-AIC framework. 627 Behavioral Ecology and Sociobiology. 65(1), 77-89. doi: 10.1007/s00265-010-1035-8 
Rohr, J. R., Dobson, A. P., Johnson, P. T., Kilpatrick, A. M., Paull, S. H., Raffel, T. R., ... Thomas, M. B. (2011). Frontiers in climate change-disease research. Trends in Ecology and Evolution, 26(6), 270-277. doi: 10.1016/j.tree.2011.03.002

Ron, S. (2005). Predicting the distribution of the amphibian pathogen Batrachochytrium dendrobatidis in the New World. Biotropica, 37(2), 209-221. doi: 10.1111/j.1744-7429.2005.00028.x

Ruggeri, J., de Carvalho-e-Silva, S. P., James, T. Y., \& Toledo, L. F. (2018). Amphibian chytrid infection is influenced by rainfall seasonality and water availability. Diseases of Aquatic Organisms, 127(2), 107-115. doi: 10.3354/dao03191

Sapsford, S. J., Alford, R. A., \& Schwarzkopf, L. (2013). Elevation, temperature, and aquatic connectivity all influence the infection dynamics of the amphibian chytrid fungus in adult frogs. PLoS ONE, 8, e82425. doi: 10.1371/journal.pone.0082425

Scheele, B. C., Pasmans, F., Skerratt, L. F., Berger, L., Martel, A., Beukema, W., ... De la Riva, I. (2019). Amphibian fungal panzootic causes catastrophic and ongoing loss of biodiversity. Science, 363(6434), 1459-1463. doi: 10.1126/science.aav0379

Seburn, C. N. L. (1992). Management plan for the Northern Leopard Frog in Alberta. Unpublished report, Alberta Forestry, Lands and Wildlife, Edmonton, AB, p. 52.

Spitzen-van der Sluijs, A., Canessa, S., Martel, A., \& Pasmans, F. (2017). Fragile coexistence of a global chytrid pathogen with amphibian populations is mediated by environment and demography. Proceedings of the Royal Society of London. Series B: Biological Sciences, 284(1864), 20171444. doi: 10.1098/rspb.2017.1444

St-Amour, V., Wong, W. M., Garner, T. W. J., \& Lesbarrères, D. (2008). Anthropogenic influence on prevalence of 2 amphibian parasites. Emerging Infectious Diseases, 14(7), 1175-1176. doi: 10.3201/eid1407.070602 
652 Statistics Canada (2011). Rivers (lines), 2011 Census - Boundary files (water file, 653 ghy_000d11a_e.zip). Arc Info Edition. Available: https://www12.statcan.gc.ca/census654 recensement/2011/geo/bound-limit/bound-limit-2011-eng.cfm [accessed: 2015 655 November 20]. System requirements: Arc Info Interchange for Windows.

656 Stebbins, R. C. (2003). A field guide to western reptiles and amphibians (3rd ed.). 657 Houghton Mif in Company, Boston, MA.

658 Tobler, U., Borgula, A., \& Schmidt, B. R. (2012). Populations of a susceptible 659 amphibian species can grow despite the presence of a parasitic chytrid fungus. PLoS 660 ONE, 7(4), e34667. doi: 10.1371/journal.pone.0034667

661 Voordouw, M. J., Adama, D., Houston, B., Govindarajulu, P., \& Robinson, J. (2010). 662 Prevalence of the pathogenic chytrid fungus, Batrachochytrium dendrobatidis, in an 663 endangered population of northern leopard frogs, Rana pipiens. BMC Ecology, 10(1), 664 6. doi: $10.1186 / 1472-6785-10-6$

665 Walther, G. R., Post, E., Convey, P., Menzel, A., Parmesan, C., Beebee, T. J. C., ... 666 Bairlein, F. (2002). Ecological responses to recent climate change. Nature, 416(6879), 667 389-395. doi: 10.1038/416389a

668 Waye,H. L., \& Cooper, J. M. (2000). Status of the Northern leopard frog (Rana pipiens) 669 in the Creston Valley Wildlife Management Area 1999. Report to the Columbia Basin 670 Fish and Wildlife Compensation Program. Nelson, BC.

671 Wilber, M. Q., Knapp, R. A., Toothman, M., \& Briggs, C. J. (2017). Resistance, 672 tolerance and environmental transmission dynamics determine host extinction risk in a 673 load-dependent amphibian disease. Ecology Letters, 20(9), 1169-1181. doi: $674 \quad$ 10.1111/ele.12814

675 Woodhams, D. C., Alford, R. A., Briggs, C. J., Johnson, M., \& Rollins-Smith, L. A. 
676 (2008). Life-history trade-offs influence disease in changing climates: strategies of an 677 amphibian pathogen. Ecology, 89(6), 1627-1639. doi: 10.1890/06-1842.

678 Wright, A. H., \& Wright, A. A. (1949). Handbook of frogs and toads of the United

679 States and Canada ( $3^{\text {rd }}$ ed.). Comstock Publishing Associates, Ithaca, New York.

680 Xie, G. Y., Olson, D. H., \& Blaustein, A. R. (2016). Projecting the global distribution 681 of the emerging amphibian fungal pathogen, Batrachochytrium dendrobatidis, based 682 on IPCC climate futures. PLoS ONE, 11(8), e0160746. doi: 683 10.1371/journal.pone.016074

684 Yuan, Z., Zhou, W., Chen, X., Poyarkov, N. A., Chen, H., Jang-Liaw, N., ... Che, J. 685 (2016). Spatiotemporal diversification of the true frogs (genus Rana): a historical 686 framework for a widely studied group of model organisms. Systematic Biology, 65(5), 687 824-842. doi: 10.1093/sysbio/syw05 
Fig. 1. $B d$ infection prevalence (\%) in R. pipiens populations collected from 41 sites in Ontario from $2012-2014$ (includes the 14 repeat sites). Pie chart denotes prevalence (red: $B d+v e$, blue: $B d$-ve), with sample size noted in brackets. Data loggers symbolized by orange markers, weather stations symbolized by green.
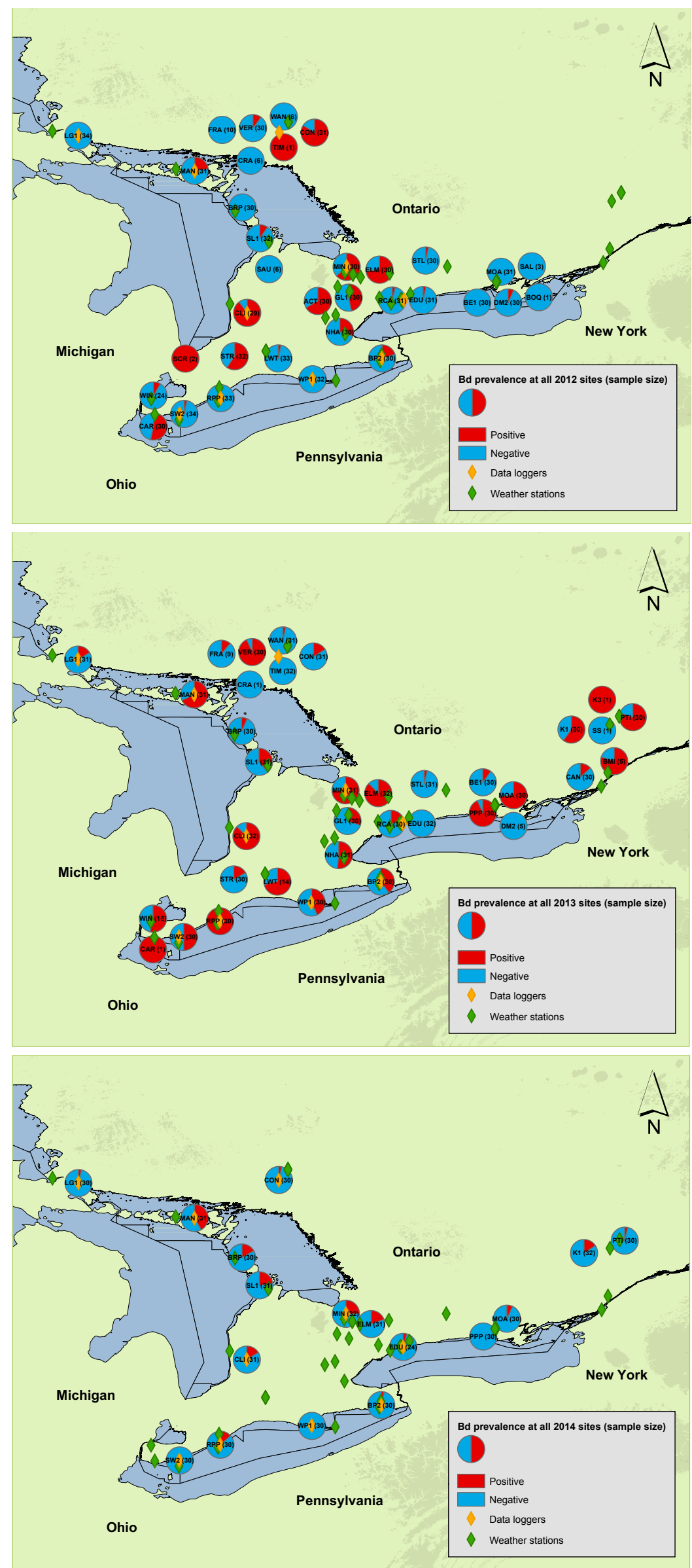
Fig. 2. Stacked bar charts representing the $B d$ prevalence (\%) and infection intensity (GE), by year, for the 14 repeat sites (with at least 24 frogs sampled per year). Within a site, $\%$ of individuals are grouped by $B d$ intensity categories (including $B d$ negative).
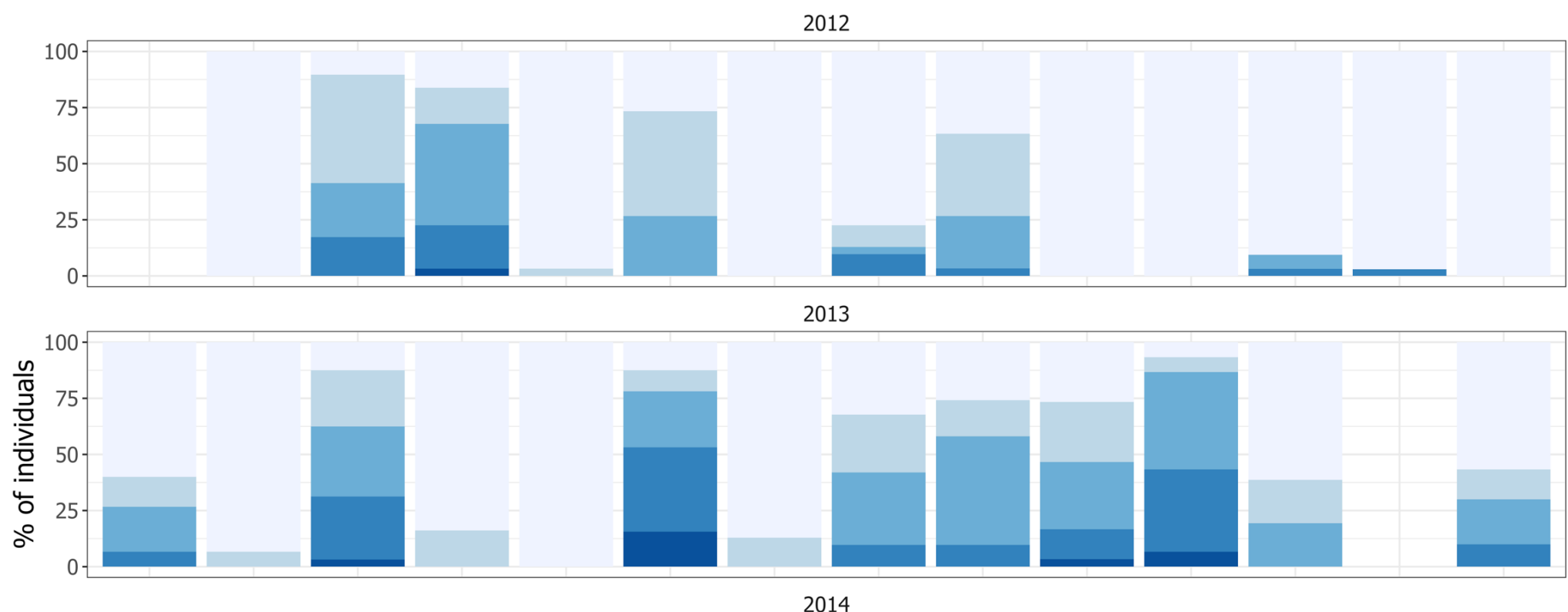

Bd intensity (GE)

$\mathrm{Bd}$ negative

$0.1-10$

$10-100$

$100-1000$

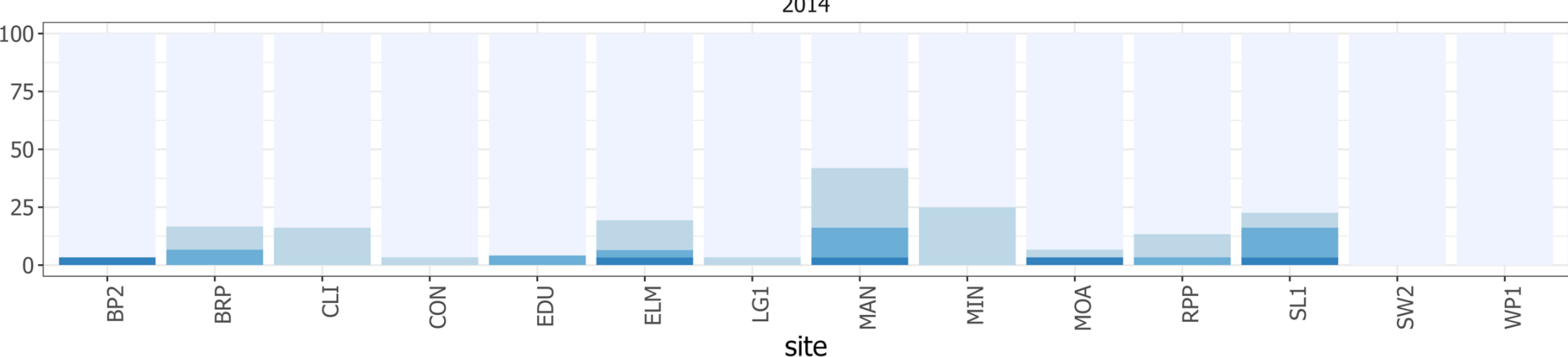


Table 1. Summary statistics for mean daily air temperature $\left({ }^{\circ} \mathrm{C}\right)$ and mean precipitation $(\mathrm{mm})$ throughout both: active period and breeding period, within all sample years.

\begin{tabular}{|c|c|c|c|c|c|c|c|c|c|c|c|c|c|c|c|c|}
\hline & \multicolumn{4}{|c|}{$\begin{array}{l}\text { Mean daily air } \\
\text { temperature }\left({ }^{\circ} \mathrm{C}\right) \\
\text { throughout } \\
\text { active period } \\
\end{array}$} & \multicolumn{4}{|c|}{$\begin{array}{l}\text { Mean daily air } \\
\text { temperature }\left({ }^{\circ} \mathrm{C}\right) \\
\text { throughout } \\
\text { breeding period }\end{array}$} & \multicolumn{4}{|c|}{$\begin{array}{c}\text { Mean precipitation }(\mathrm{mm}) \\
\text { throughout } \\
\text { active period }\end{array}$} & \multicolumn{4}{|c|}{$\begin{array}{c}\text { Mean precipitation }(\mathrm{mm}) \\
\text { throughout } \\
\text { breeding period }\end{array}$} \\
\hline & $\overline{\mathbf{x}}$ & se & $\max$ & range & $\overline{\mathbf{x}}$ & se & $\max$ & range & $\overline{\mathbf{x}}$ & se & $\max$ & range & $\overline{\mathbf{x}}$ & se & $\max$ & range \\
\hline 2012 & 7.7 & 0.2 & 10.2 & 4.4 & 17.1 & 0.3 & 19.4 & 7.2 & 66.3 & 1.0 & 76.5 & 20.5 & 72.6 & 0.9 & 81.0 & 18.5 \\
\hline 2013 & 6.9 & 0.2 & 11.7 & 6.8 & 16.0 & 0.2 & 20.4 & 7.8 & 69.5 & 1.3 & 88.0 & 31.0 & 73.0 & 1.1 & 86.5 & 23.0 \\
\hline 2014 & 7.5 & 0.2 & 9.8 & 4.1 & 17.5 & 0.2 & 20.3 & 5.7 & 66.3 & 1.2 & 76.5 & 17.5 & 72.0 & 1.3 & 80.0 & 17.5 \\
\hline
\end{tabular}

Table 2. Summary statistics for spring onset (decimal date), calling date (decimal date) and active period (days), from 2011 to 2015.

\begin{tabular}{|c|c|c|c|c|c|c|c|c|c|c|c|c|c|c|c|}
\hline & \multicolumn{5}{|c|}{ Spring onset (decimal date) } & \multicolumn{5}{|c|}{ Calling date (decimal date) } & \multicolumn{5}{|c|}{ Active period (days) } \\
\hline & $\overline{\mathbf{x}}$ & se & $\max$ & mode & range & $\overline{\mathbf{x}}$ & se & $\max$ & mode & range & $\overline{\mathbf{x}}$ & se & $\max$ & mode & range \\
\hline 2011 & 90.36 & 1.75 & 111 & 88 & 44 & 145.58 & 1.82 & 164 & 148 & 39 & 55.21 & 2.03 & 80 & 60 & 43 \\
\hline 2012 & 71.18 & 0.69 & 92 & 71 & 26 & 119.79 & 4.91 & 165 & 138 & 94 & 48.61 & 4.80 & 94 & 67 & 92 \\
\hline 2013 & 99.03 & 1.83 & 122 & 94 & 41 & 123.76 & 2.02 & 157 & 120 & 40 & 24.73 & 2.19 & 64 & 26 & 59 \\
\hline 2014 & 95.60 & 1.76 & 108 & 107 & 22 & 136.12 & 1.26 & 149 & 138 & 28 & 40.52 & 1.73 & 62 & 52 & 43 \\
\hline 2015 & 91.18 & 1.29 & 98 & 97 & 31 & 125.06 & 2.58 & 164 & 118 & 64 & 33.88 & 3.16 & 74 & 30 & 69 \\
\hline
\end{tabular}

Table 3. Spring onset (decimal date), calling date (decimal date) and active period (days), by year. $\mathbf{Y}_{\mathbf{D}}$, difference in decimal dates between current year and the previous year; $\%_{\mathbf{V}}$, percentage change between current year and the previous year; $\mathbf{T}_{\mathbf{v}}$, total inter-annual variation in decimal days irrespective of directionality; $\mathbf{T}_{\mathbf{V D}}$, total inter-annual variation in decimal days respective of directionality; $\mathbf{T}_{\mathbf{V D}} / \mathbf{Y}$, average variation per annum in decimal days, respective of directionality

\begin{tabular}{|c|c|c|c|c|c|c|c|c|c|}
\hline & \multicolumn{3}{|c|}{$\begin{array}{l}\text { Spring onset (decimal date), } \\
\text { by year }\end{array}$} & \multicolumn{3}{|c|}{$\begin{array}{c}\text { Calling date (decimal date), } \\
\text { by year }\end{array}$} & \multicolumn{3}{|c|}{$\begin{array}{c}\text { Active period (days), } \\
\text { by year }\end{array}$} \\
\hline & $\begin{array}{c}\overline{\mathbf{x}} \\
\text { decimal } \\
\text { date }\end{array}$ & $\mathbf{Y}_{\mathbf{D}}$ & $\% v$ & $\begin{array}{l}\text { Decimal } \\
\text { date }\end{array}$ & $\mathbf{Y}_{\mathbf{D}}$ & $\% v$ & Days & $\mathbf{Y}_{\mathbf{D}}$ & $\% v$ \\
\hline 2011 & 90.36 & & & 145.58 & & & 55.21 & & \\
\hline 2012 & 71.18 & -19.18 & -21.22 & 119.79 & -25.79 & -17.72 & 48.61 & -6.60 & -11.95 \\
\hline 2013 & 99.03 & +27.85 & $\begin{array}{r}+39.13 \\
\end{array}$ & 123.76 & +3.97 & +3.31 & 24.73 & -23.88 & -49.12 \\
\hline 2014 & 95.61 & -3.42 & +3.45 & 136.12 & +12.36 & +9.99 & 40.52 & $\begin{array}{r}+15.79 \\
\end{array}$ & +63.85 \\
\hline 2015 & 91.18 & -4.43 & +4.63 & 125.06 & -11.06 & -8.13 & 33.88 & -6.64 & -16.39 \\
\hline $\mathbf{T}_{\mathrm{V}}$ & & 54.88 & & & 53.18 & & & 52.91 & \\
\hline $\mathbf{T}_{\mathrm{VD}}$ & & +0.82 & & & -20.52 & & & -21.33 & \\
\hline $\mathbf{T}_{\mathbf{V D}} / \mathbf{Y}$ & & +0.21 & & & -5.13 & & & -5.33 & \\
\hline
\end{tabular}


Table 4. Model averaged estimates and confidence intervals (2.5\% and $97.5 \%)$ for the models in the delta-6 top model set remaining after the nesting rule has been applied, for both $B d$ prevalence (\%; models remaining $=4$ ) and $B d$ intensity of infection (GE; models remaining $=3$ ). Calculated using both: (1) conditional average: averages over the models where the parameter appears, and (2) full average: model averaged estimates calculated using the 'zeroes' method where estimates are set to zero in models where they do not occur. 'Importance': relative variable importance, calculated as the sum of the Akaike weights of the models in which that term occurred.

\begin{tabular}{|c|c|c|c|c|c|c|c|}
\hline & \multirow{2}{*}{ Importance } & \multicolumn{3}{|c|}{ Conditional } & \multicolumn{3}{|c|}{ Full } \\
\hline & & Estimate & $2.5 \%$ & $97.5 \%$ & Estimate & $2.5 \%$ & $\mathbf{9 7 . 5 \%}$ \\
\hline \multicolumn{8}{|l|}{$B d$ prevalence } \\
\hline intercept & - & -1.502 & -2.422 & -0.582 & -1.502 & -2.422 & -0.582 \\
\hline factor(year)2013 & 1.00 & 1.248 & 0.572 & 1.925 & 1.248 & 0.572 & 1.925 \\
\hline factor(year)2014 & 1.00 & -1.109 & -1.654 & -0.564 & -1.109 & -1.654 & -0.564 \\
\hline active period length & 0.39 & -0.274 & -0.092 & 0.639 & -0.085 & -0.236 & 0.406 \\
\hline active period mean temperature & 0.73 & -0.349 & -0.532 & 0.167 & -0.214 & -0.577 & 0.148 \\
\hline active period length $*$ active period mean temperature & 0.39 & 0.245 & 0.018 & 0.509 & 0.076 & -0.190 & 0.343 \\
\hline breeding period mean temperature & 0.39 & 0.362 & 0.167 & 0.556 & 0.075 & -0.226 & 0.377 \\
\hline \multicolumn{8}{|l|}{$B d$ intensity of infection } \\
\hline intercept & - & 2.275 & 0.858 & 3.693 & 2.275 & 0.858 & 3.693 \\
\hline factor(year)2013 & 1.00 & 1.840 & 0.365 & 3.316 & 1.840 & 0.365 & 3.316 \\
\hline factor(year)2014 & 1.00 & -1.731 & -3.167 & -0.294 & -1.731 & -3.167 & -0.294 \\
\hline river density & 0.56 & 0.232 & -0.701 & 1.165 & 0.109 & -0.571 & 0.791 \\
\hline breeding period mean precipitation & 0.56 & 0.322 & -0.511 & 1.155 & 0.152 & -0.502 & 0.807 \\
\hline hydroshed area & 0.96 & -2.195 & -6.008 & 1.618 & -2.080 & -5.913 & 0.753 \\
\hline river density $*$ breeding period mean precipitation & 0.56 & 1.533 & 0.210 & 2.857 & 0.727 & -1.029 & 2.482 \\
\hline
\end{tabular}


Fig. 3. Model predicted relationship between $B d$ prevalence $(\%)$ and the following interaction: mean daily air temperature $\left({ }^{\circ} \mathrm{C}\right)$ during active period (negatively correlated) and length of active period (days; positively correlated). The three lines represent the relationship between $B d$ prevalence and mean daily air temperature during the active period when length of active period is held at: i) its global mean (sold black line), ii) one standard deviation below the global mean (dotted line, light green shaded area spans the $95 \%$ credible intervals for the fitted means), iii) one standard deviation above the global mean (long dashed line, dark green shaded area spans the 95\% credible intervals for the fitted means). Variation in $B d$ prevalence is greatest when active periods are shortened and temperatures are cool. If active periods are extended, the relationship between $B d$ prevalence and mean daily air temperature diminishes. However, if active periods are shortened, this relationship becomes more negative.

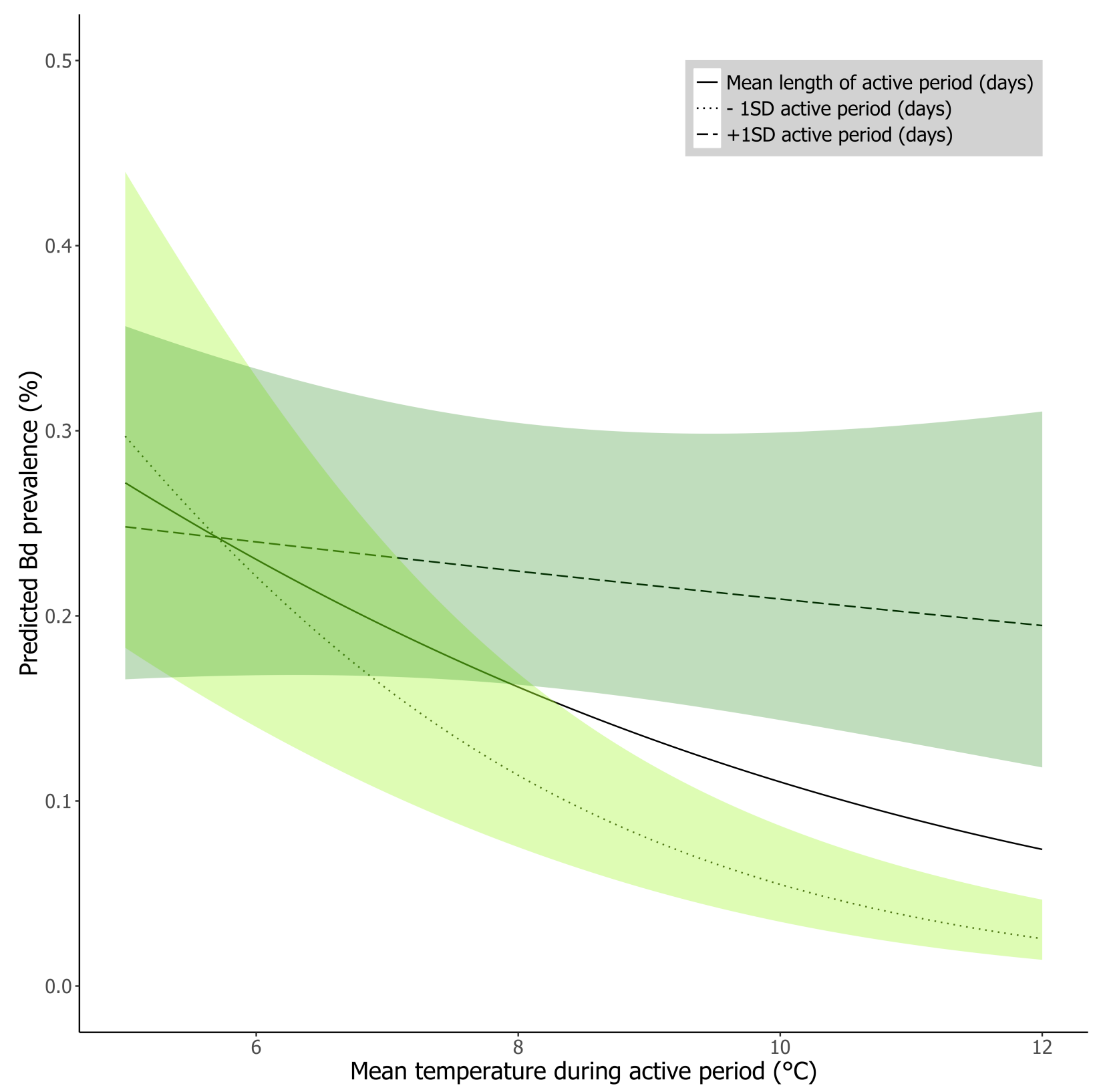


Fig. 4. Model predicted relationship between $B d$ mean intensity (GE) and hydroshed area $\left(\mathrm{km}^{2}\right)$. After an initial rapid exponential decrease, mean infection intensity reaches a plateau at very low intensities/ zero infection at approximately $20,000 \mathrm{~km}^{2}$.

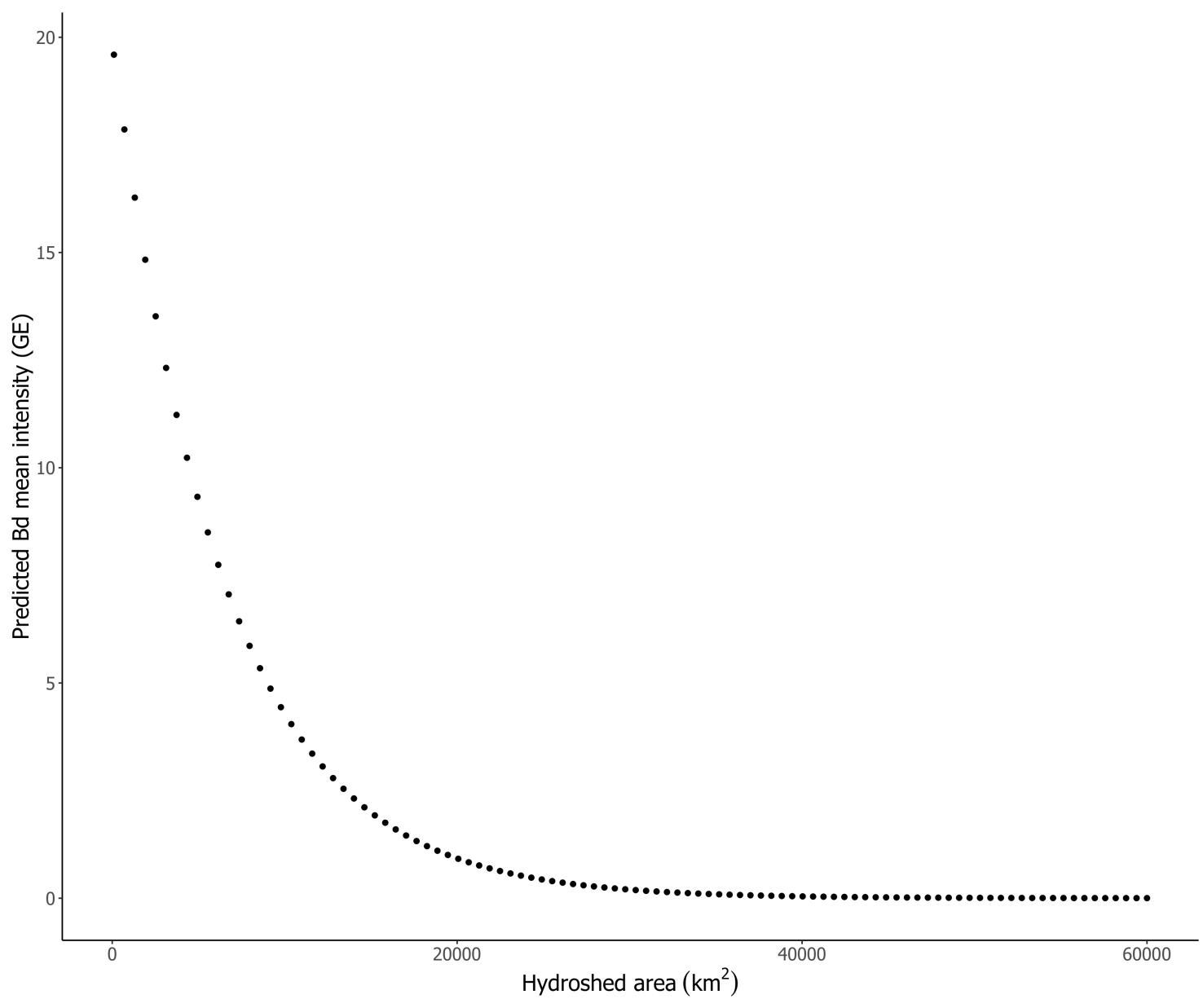


Fig. 5. Model predicted relationship between $B d$ mean intensity (GE) and the following interaction: river density (within $10 \mathrm{~km}$ buffer from site centroid; positively correlated) and mean precipitation $(\mathrm{mm})$ throughout breeding period (positively correlated). The three lines represent the relationship between $B d$ mean intensity and mean precipitation throughout breeding period, when river density is held at: i) its global mean (sold black line, orange shaded area spans the $95 \%$ credible intervals for the fitted means), ii) one standard deviation below the global mean (dotted line), iii) one standard deviation above the global mean (long dashed line). $B d$ mean intensity is greatest when a site locality is in close proximity to a dense network of rivers, and precipitation is high. If river densities are low, $B d$ mean intensity increases slightly when precipitation levels are low.

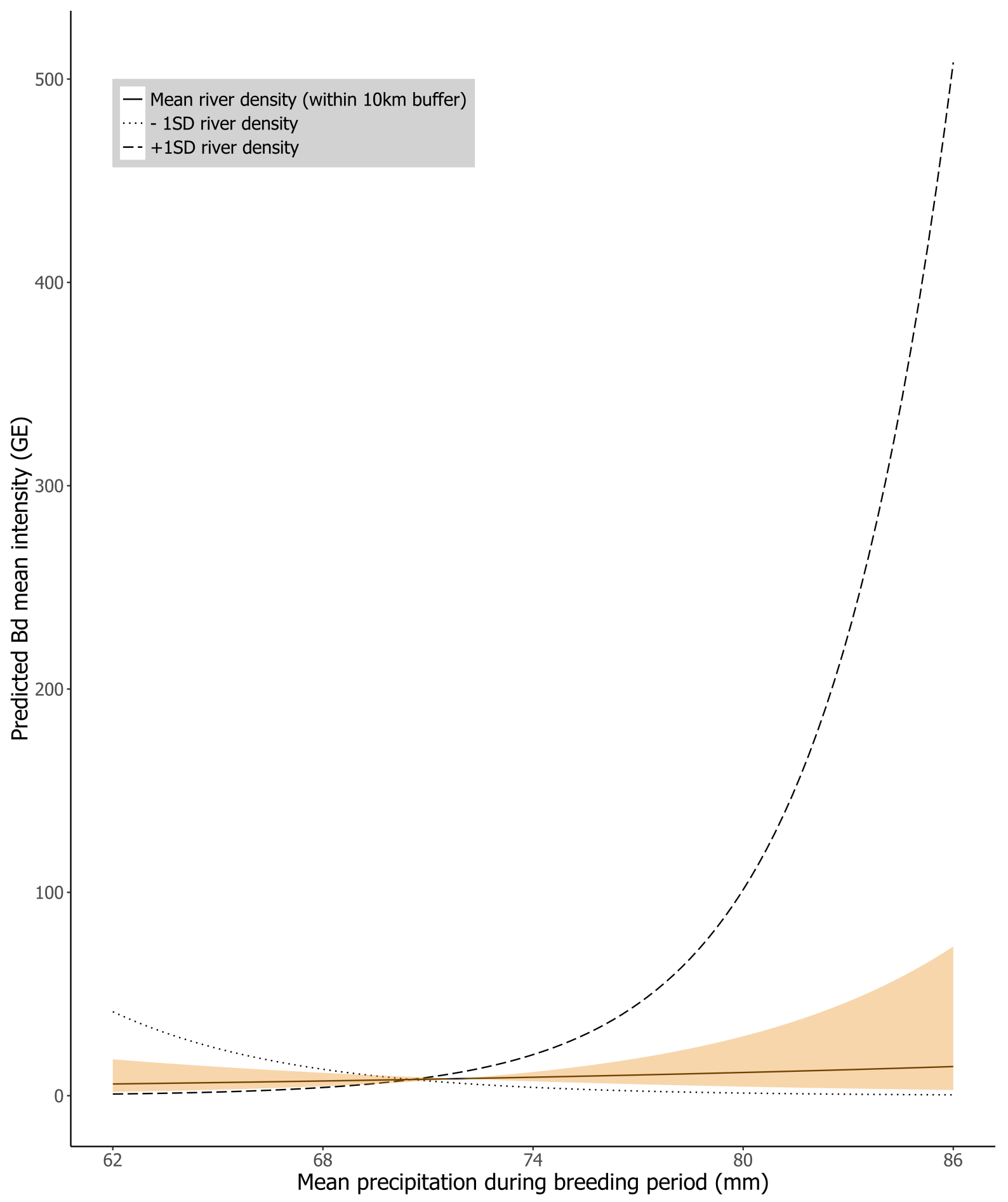


Fig. S1. The distribution of the R.pipiens throughout Ontario. Includes both historic and recent observations compiled from data recorded by Bird Studies Canada: Marsh Monitoring Program, and Ontario Nature: Ontario Reptile and Amphibian Atlas and the Original Herpetofaunal Summary. Atlas squares are based on a 5 x $5 \mathrm{~km}$ grid. Areas without squares do not indicate the absence of the species, but only that there are no observation data to confirm the presence of the species in those areas.

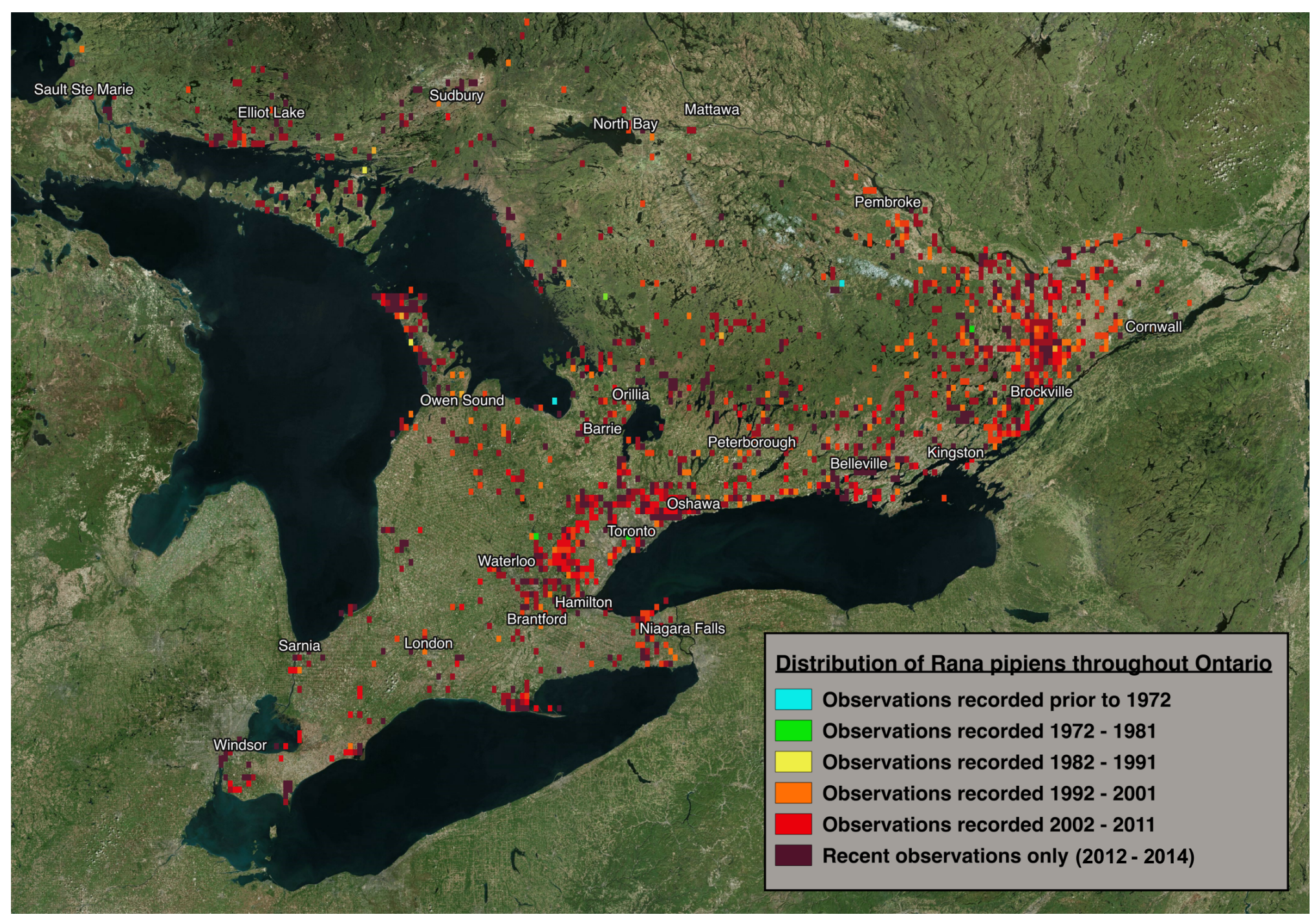


Fig. S2. Stacked bar charts representing $B d$ prevalence (\%) and infection intensity (GE), by year. Individual counts of infection intensity are labeled in blue; proportion of infected and non-infected individuals are labeled as percentages; and samples sizes are denoted on top. Note greater prevalence and higher infection intensity recorded in 2013.

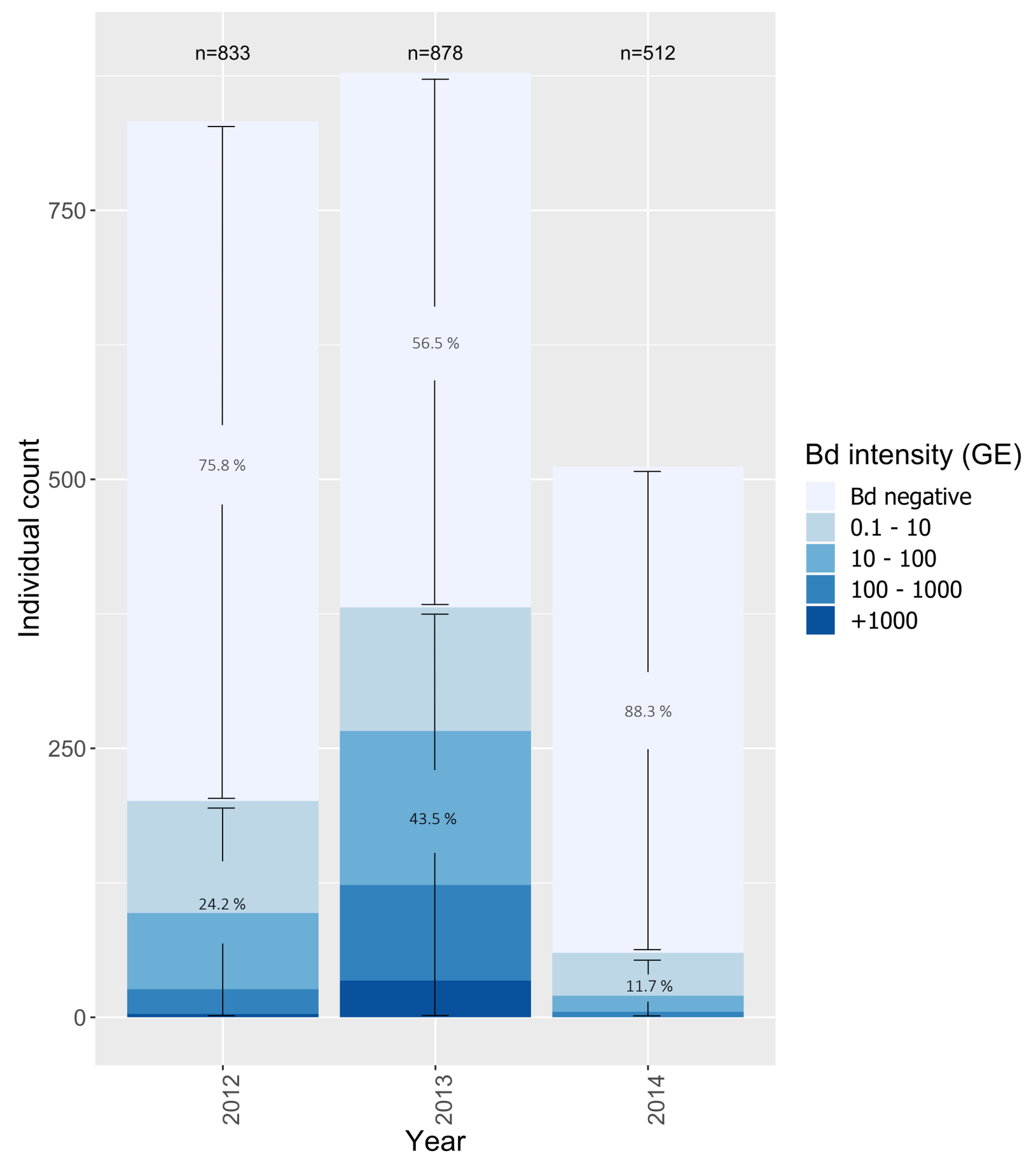


Fig. S3. Density plot of $\log B d$ intensity (GE), by year. Note the lower density of zero/ low infections in 2013 , in comparison to 2012 and 2014 , and again a greater density of strong infections in 2013, in comparison to 2012 and 2014.

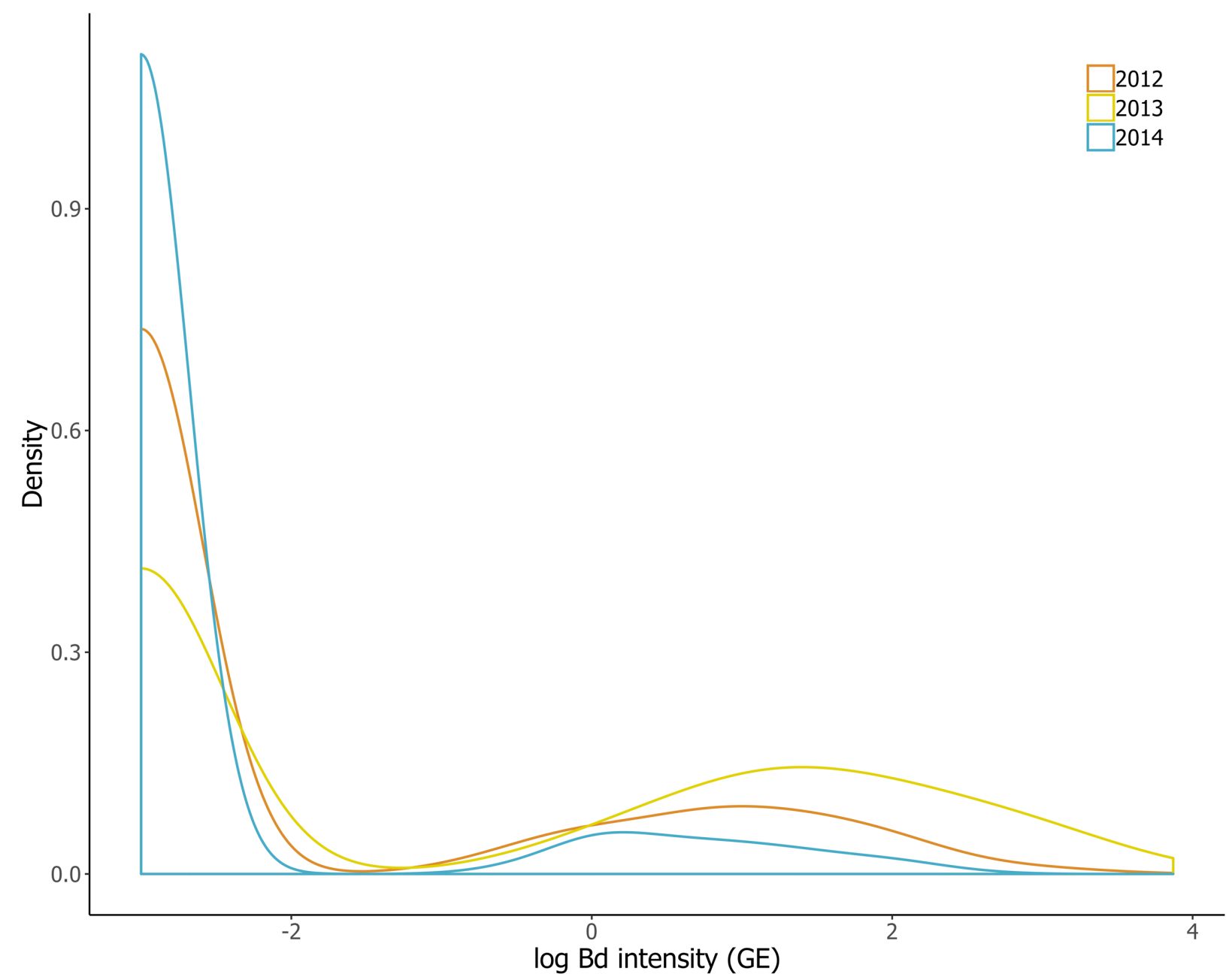




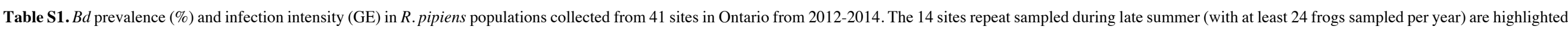
in the far-right column.

\begin{tabular}{|c|c|c|c|c|c|c|}
\hline Site & Year & Sample size & \% Prevalence ( $\mathrm{N}=$ Individuals $B d$ positive) & Mean infection intensity (SE, range) & $\begin{array}{c}\text { Temperature and precipitation data compiled } \\
\text { (logger or weather station) }\end{array}$ & Repeat sampled \\
\hline ACT & 2012 & 30 & $66.7(20)$ & $104.92(89.9,0.21-2708.28)$ & $\sqrt{2}$ & \\
\hline \multirow[t]{2}{*}{ BE1 } & 2012 & 30 & $0(0)$ & 0 & $\sqrt{2}$ & \\
\hline & 2013 & 30 & $10(3)$ & $0.24(0.17,0.56-4.83)$ & 2 & \\
\hline BMI & 2013 & 5 & $80(4)$ & $22.34(18.82,0.56-97.31)$ & $x$ & \\
\hline BOQ & 2012 & 1 & $0(0)$ & 0 & $x$ & \\
\hline \multirow[t]{3}{*}{ BP2 } & 2012 & 30 & $20(6)$ & $1.0(0.49,0.52-11.63)$ & $\checkmark$ & \\
\hline & 2013 & 30 & $40(12)$ & $20.25(7.99,1.98-199.09)$ & $\checkmark$ & $*$ \\
\hline & 2014 & 30 & $3.3(1)$ & $4.01(4.01,120.44-120.44)$ & 2 & $*$ \\
\hline \multirow[t]{3}{*}{ BRP } & 2012 & 30 & $0(0)$ & 0 & $\sqrt{2}$ & $*$ \\
\hline & 2013 & 30 & $6.7(2)$ & $0.08(0.07,0.32-2.09)$ & $\sqrt{2}$ & $*$ \\
\hline & 2014 & 30 & $16.7(5)$ & $2.42(1.39,2.93-35.79)$ & $\vec{v}$ & $*$ \\
\hline CAN & 2013 & 30 & $13.3(4)$ & $0.74(0.49,0.47-11.41)$ & $\sqrt{2}$ & \\
\hline \multirow[t]{2}{*}{ CAR } & 2012 & 30 & $53.3(16)$ & $3.9(1.79,0.14-42.39)$ & 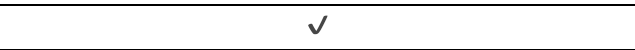 & \\
\hline & 2013 & 1 & $100(1)$ & $0.32(0,0.32-0.32)$ & $\checkmark$ & \\
\hline \multirow[t]{3}{*}{ CLI } & 2012 & 29 & $89.7(26)$ & $51.47(22.75,0.52-622.49)$ & 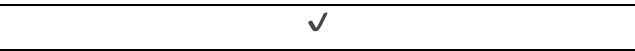 & $*$ \\
\hline & 2013 & 32 & $87.5(28)$ & $158.27(54.84,0.65-1323.62)$ & $\checkmark$ & $*$ \\
\hline & 2014 & 31 & $16.1(5)$ & $0.78(0.4,0.98-7.72)$ & $\checkmark$ & $*$ \\
\hline \multirow[t]{3}{*}{$\mathrm{CON}$} & 2012 & 31 & $83.9(26)$ & $127.8(46.65,0.92-1022.6)$ & $\sqrt{2}$ & $*$ \\
\hline & 2013 & 31 & $16.1(5)$ & $0.25(0.18,0.3-5.49)$ & $\sqrt{2}$ & $*$ \\
\hline & 2014 & 30 & $3.3(1)$ & $0.09(0.09,2.6-2.6)$ & 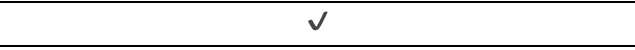 & $*$ \\
\hline \multirow[t]{2}{*}{ CRA } & 2012 & 6 & $0(0)$ & 0 & $x$ & \\
\hline & 2013 & 1 & $0(0)$ & 0 & $x$ & \\
\hline \multirow[t]{2}{*}{ DM2 } & 2012 & 30 & $6.7(2)$ & $1.45(1.45,0.09-43.47)$ & $\sqrt{2}$ & \\
\hline & 2013 & 5 & $0(0)$ & 0 & 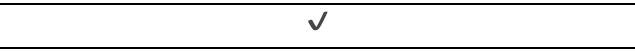 & \\
\hline \multirow[t]{3}{*}{ EDU } & 2012 & 31 & $3.2(1)$ & $0.05(0.05,1.52-1.52)$ & $\sqrt{2}$ & $*$ \\
\hline & 2013 & 32 & $0(0)$ & 0 & 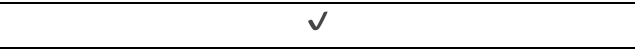 & $*$ \\
\hline & 2014 & 24 & $4.2(1)$ & $1.27(1.27,30.47-30.47)$ & $\sqrt{2}$ & $*$ \\
\hline \multirow[t]{3}{*}{ ELM } & 2012 & 30 & $73.3(22)$ & $8.46(2.63,0.12-58.69)$ & $\checkmark$ & $*$ \\
\hline & 2013 & 32 & $87.5(28)$ & $484.97(141.23,3.61-3371.34)$ & $\sqrt{2}$ & $*$ \\
\hline & 2014 & 31 & $19.4(6)$ & $5.95(4.23,0.24-116.57)$ & $\checkmark$ & $*$ \\
\hline
\end{tabular}




\begin{tabular}{|c|c|c|c|c|c|c|}
\hline Site & Year & Sample size & $\%$ Prevalence $(\mathrm{N}=$ Individuals $\mathrm{Bd}$ positive $)$ & Mean infection intensity (SE, range) & $\begin{array}{l}\text { Temperature and precipitation data compiled } \\
\text { (logger or weather station) }\end{array}$ & Repeat sampled \\
\hline \multirow[t]{2}{*}{ FRA } & 2012 & 10 & $0(0)$ & 0 & $x$ & \\
\hline & 2013 & 9 & $11.1(1)$ & $0.08(0.08,0.72-0.72)$ & $x$ & \\
\hline \multirow[t]{2}{*}{ GL1 } & 2012 & 30 & $46.7(14)$ & $21.7(9.86,0.27-256.42)$ & $\checkmark$ & \\
\hline & 2013 & 30 & $30(9)$ & $5.7(3.43,0.83-96.61)$ & $\checkmark$ & \\
\hline \multirow[t]{2}{*}{ K1 } & 2013 & 30 & $60(18)$ & $42.24(15.66,0.29-426.67)$ & $\checkmark$ & \\
\hline & 2014 & 32 & $15.6(5)$ & $0.92(0.51,1.29-14.77)$ & 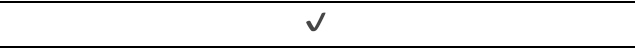 & \\
\hline $\mathrm{K} 3$ & 2013 & 1 & $100(1)$ & $20.76(0,20.76-20.76)$ & $x$ & \\
\hline \multirow[t]{3}{*}{ LG1 } & 2012 & 34 & $0(0)$ & 0 & $\checkmark$ & $*$ \\
\hline & 2013 & 31 & $16.1(5)$ & $0.43(0.31,0.02-9.25)$ & $\checkmark$ & $*$ \\
\hline & 2014 & 30 & $3.3(1)$ & $0.04(0.04,1.13-1.13)$ & $\checkmark$ & $*$ \\
\hline \multirow[t]{2}{*}{ LWT } & 2012 & 33 & $3(1)$ & $0.45(0.45,14.97-14.97)$ & $\checkmark$ & \\
\hline & 2013 & 14 & $71.4(10)$ & $25.12(15.72,1.15-221.86)$ & $\checkmark$ & \\
\hline \multirow[t]{3}{*}{ MAN } & 2012 & 31 & $22.6(7)$ & $16.39(8.33,2.58-167.84)$ & $\checkmark$ & $*$ \\
\hline & 2013 & 31 & $67.7(21)$ & $36.01(12.98,0.84-307.94)$ & $\checkmark$ & $*$ \\
\hline & 2014 & 31 & $41.9(13)$ & $7.05(3.93,0.57-117.91)$ & $\checkmark$ & $*$ \\
\hline \multirow[t]{3}{*}{ MIN } & 2012 & 30 & $63.3(19)$ & $9.34(3.8,0.18-100.78)$ & $\checkmark$ & $*$ \\
\hline & 2013 & 31 & $74.2(23)$ & $39.87(14.28,1.48-424.68)$ & $\checkmark$ & $*$ \\
\hline & 2014 & 32 & $25(8)$ & $0.72(0.35,0.35-7.93)$ & $\checkmark$ & $*$ \\
\hline \multirow[t]{3}{*}{ MOA } & 2012 & 31 & $0(0)$ & 0 & $\checkmark$ & $*$ \\
\hline & 2013 & 30 & $73.3(22)$ & $149.52(85.62,0.58-2407.03)$ & $\checkmark$ & $*$ \\
\hline & 2014 & 30 & $6.7(2)$ & $10.43(10.41,0.67-312.27)$ & $\checkmark$ & $*$ \\
\hline \multirow[t]{2}{*}{ NHA } & 2012 & 30 & $30(9)$ & $2.31(1.16,0.27-26.43)$ & $\checkmark$ & \\
\hline & 2013 & 31 & $51.6(16)$ & $121.64(51.47,4.69-1400.91)$ & $\checkmark$ & \\
\hline \multirow[t]{2}{*}{ PPP } & 2013 & 30 & $93.3(28)$ & $1001.34(292.82,1.08-7427.23)$ & $\checkmark$ & \\
\hline & 2014 & 30 & $0(0)$ & 0 & $\checkmark$ & \\
\hline \multirow[t]{2}{*}{ PTI } & 2013 & 30 & $80(24)$ & $486.15(176.71,0.43-4166.62)$ & $\checkmark$ & \\
\hline & 2014 & 30 & $3.3(1)$ & $2.6(2.6,78.09-78.09)$ & $\checkmark$ & \\
\hline \multirow[t]{2}{*}{ RCA } & 2012 & 31 & $3.2(1)$ & $4.4(4.4,136.48-136.48)$ & $\checkmark$ & \\
\hline & 2013 & 30 & $20(6)$ & $63.39(58.13,2.61-1746.99)$ & $\checkmark$ & \\
\hline \multirow[t]{3}{*}{ RPP } & 2012 & 33 & $0(0)$ & 0 & $\checkmark$ & $*$ \\
\hline & 2013 & 30 & $93.3(28)$ & $216.69(60.06,3.79-1230.34)$ & $\checkmark$ & $*$ \\
\hline & 2014 & 30 & $13.3(4)$ & $0.93(0.59,0.82-15.19)$ & $\checkmark$ & $*$ \\
\hline SAL & 2012 & 3 & $0(0)$ & 0 & $x$ & \\
\hline SAU & 2012 & 6 & $0(0)$ & 0 & $x$ & \\
\hline
\end{tabular}




\begin{tabular}{|c|c|c|c|c|c|c|}
\hline Site & Year & Sample size & $\%$ Prevalence ( $\mathbf{N}=$ Individuals $B d$ positive) & Mean infection intensity (SE, range) & $\begin{array}{c}\text { Temperature and precipitation data compiled } \\
\text { (logger or weather station) }\end{array}$ & Repeat sampled \\
\hline SCR & 2012 & 2 & $100(2)$ & $343.73(342.78,0.95-686.51)$ & $x$ & \\
\hline \multirow[t]{3}{*}{ SL1 } & 2012 & 32 & $9.4(3)$ & $6.6(4.12,41.12-117.01)$ & $\checkmark$ & $*$ \\
\hline & 2013 & 31 & $38.7(12)$ & $6.16(3.1,0.16-91.78)$ & $\checkmark$ & $*$ \\
\hline & 2014 & 31 & $22.6(7)$ & $9.09(4.92,0.41-138.03)$ & $\checkmark$ & $*$ \\
\hline SS & 2013 & 1 & $0(0)$ & 0 & $x$ & \\
\hline \multirow[t]{2}{*}{ STL } & 2012 & 30 & $3.3(1)$ & $0.02(0.02,0.59-0.59)$ & $\checkmark$ & \\
\hline & 2013 & 31 & $3.2(1)$ & $0.1(0.1,3.22-3.22)$ & $\checkmark$ & \\
\hline \multirow[t]{2}{*}{ STR } & 2012 & 32 & $59.4(19)$ & $65.95(46.1,0.6-1479.94)$ & $\checkmark$ & \\
\hline & 2013 & 30 & $16.7(5)$ & $3.88(3.36,1.33-101.02)$ & $\checkmark$ & \\
\hline \multirow[t]{3}{*}{ SW2 } & 2012 & 34 & $2.9(1)$ & $9.79(9.79,332.92$ - 332.92) & $\checkmark$ & $*$ \\
\hline & 2013 & 30 & $50(15)$ & $45.84(20.67,3.37-528.43)$ & $\checkmark$ & \\
\hline & 2014 & 30 & $0(0)$ & 0 & $\checkmark$ & $*$ \\
\hline \multirow[t]{2}{*}{ TIM } & 2012 & 1 & $100(1)$ & $0.85(0,0.85-0.85)$ & $\checkmark$ & \\
\hline & 2013 & 32 & $0(0)$ & 0 & $\checkmark$ & \\
\hline \multirow[t]{2}{*}{ VER } & 2012 & 30 & $10(3)$ & $0.41(0.33,0.87-9.89)$ & $\checkmark$ & \\
\hline & 2013 & 30 & $93.3(28)$ & $1062.49(290.73,4.14-6221.99)$ & $\checkmark$ & \\
\hline \multirow[t]{2}{*}{ WAN } & 2012 & 6 & $0(0)$ & 0 & $\checkmark$ & \\
\hline & 2013 & 31 & $3.2(1)$ & $1.64(1.64,50.99-50.99)$ & $\checkmark$ & \\
\hline \multirow[t]{2}{*}{ WIN } & 2012 & 24 & $8.3(2)$ & $0.46(0.43,0.69-10.41)$ & $\checkmark$ & \\
\hline & 2013 & 15 & $53.3(8)$ & $5.87(2.3,0.77-29.9)$ & $\checkmark$ & \\
\hline \multirow[t]{3}{*}{ WP1 } & 2012 & 32 & $0(0)$ & 0 & $\checkmark$ & $*$ \\
\hline & 2013 & 30 & $43.3(13)$ & $45.49(22.89,2.7-601.2)$ & $\checkmark$ & $*$ \\
\hline & 2014 & 30 & $0(0)$ & 0 & $\checkmark$ & $*$ \\
\hline \multicolumn{2}{|c|}{ TOTAL } & 2223 (41 sites, 87 visits) & $28.9(644)$ & $61.79(7.82,0.02-7427.23)$ & 32 sites (76 visits) & 14 sites (40 visits) \\
\hline
\end{tabular}


Table S2. Spatial predictor variables selected for use in model building based on their suitability for hypothesis testing. Details regarding the variations (per grid cell), raw resolutions, year of record, unit, source, prediction and predicted relationship for all spatial predictors. "+" and "-" represent an expected positive or negative correlation, respectively.

\begin{tabular}{|c|c|c|c|c|c|c|c|c|}
\hline Predictor & $\begin{array}{l}\text { Variations } \\
\text { (per grid cell) }\end{array}$ & Raw resolution & $\begin{array}{l}\text { Year } \\
\text { recorded }\end{array}$ & Unit & Source & Prediction & $\begin{array}{l}\text { Predicted } \\
\text { relationship }\end{array}$ & $\begin{array}{l}\text { Support for } \\
\text { prediction }\end{array}$ \\
\hline Hydroshed area & total & $\begin{array}{l}30 \text { arc seconds } \\
(\sim 1 \mathrm{~km})\end{array}$ & 2008 & $\mathrm{~km}^{2}$ & $\begin{array}{l}\text { 'USGS HyrdoSHEDS' } \\
\text { http://hydrosheds.cr.usgs.gov } \\
\text { Lehner et al., } 2008\end{array}$ & $\begin{array}{l}\text { As water basins serve as likely } \\
\text { vectors for the waterborne } B d \\
\text { zoospores, an increase in basin size } \\
\text { will lower infection parameters due } \\
\text { to diluted pathogen concentrations. }\end{array}$ & - & [1-4] \\
\hline River density & mean & $\begin{array}{l}1 \times 1 \mathrm{~km} \\
(10 \mathrm{~km} \text { mean } \\
\text { extracted })\end{array}$ & 2011 & $\mathrm{~km}$ & $\begin{array}{l}2011 \text { Census -Rivers (lines)' } \\
\text { https://www12.statcan.gc.ca/census- } \\
\text { recensement/2011/geo/bound- } \\
\text { limit/bound-limit-2011-eng.cfm } \\
\text { Statistics Canada, 2011 }\end{array}$ & $\begin{array}{l}\text { Infection parameters will be } \\
\text { greatest in areas with dense river } \\
\text { networks, as it provides increased } \\
\text { transmission channels via aquatic } \\
\text { nodes. }\end{array}$ & + & {$[5-7]$} \\
\hline $\begin{array}{l}\begin{array}{l}\text { Precipitation } \\
\text { (during breeding period) }\end{array} \\
\text { Precipitation } \\
\text { (during active period) }\end{array}$ & mean & $\begin{array}{l}30 \text { arc seconds } \\
(\sim 1 \mathrm{~km})\end{array}$ & $1950-2000$ & $\mathrm{~mm}$ & $\begin{array}{l}\text { 'Current Conditions: Precipitation' } \\
\text { http://www.worldclim.org } \\
\text { Hijmans et al., } 2005\end{array}$ & $\begin{array}{l}\text { Infection parameters will increase } \\
\text { with increased precipitation, as } \\
\text { water must be present for } B d \text { to } \\
\text { infect new hosts or to re-infect } \\
\text { current hosts. }\end{array}$ & + & [7-9] \\
\hline $\begin{array}{l}\text { Air temperature } \\
\text { (during active period) }\end{array}$ & mean & N/A & $2011-2015$ & ${ }^{\circ} \mathrm{C}$ & $\begin{array}{l}\text { Calculated from data loggers and } \\
\text { historical data from weather stations } \\
\text { (see Fig. S1). }\end{array}$ & $\begin{array}{l}\text { Infection parameters will increase } \\
\text { as temperatures decrease. }\end{array}$ & - & [10-12] \\
\hline $\begin{array}{l}\text { Length of active period } \\
\text { (days between spring } \\
\text { onset and calling date) }\end{array}$ & total & & & days & $\begin{array}{l}\text { http://climate.weather.gc.ca/historic } \\
\text { al_data/search_historic_data_e.html } \\
\text { Government of Canada, 2015a }\end{array}$ & $\begin{array}{l}\text { As length of active period is } \\
\text { elongated, infection parameters will } \\
\text { increase due to expanded } \\
\text { opportunities for successful } \\
\text { pathogen transmission. }\end{array}$ & + & [13] \\
\hline Road density & mean & $\begin{array}{l}1 \times 1 \mathrm{~km} \\
(50 \mathrm{~km} \text { mean } \\
\text { extracted })\end{array}$ & 2015 & $\mathrm{~mm}$ & $\begin{array}{l}\text { 'National Road Network (NRN) - } \\
\text { Ontario.' } \\
\text { https://open.canada.ca/data/en/datas } \\
\text { et/3d282116-e556-400c-9306- } \\
\text { ca1a3cada77f } \\
\text { Government of Canada, 2015b }\end{array}$ & $\begin{array}{l}\text { Increased road density will intensify } \\
\text { landscape fragmentation leading to } \\
\text { isolated habitat patches and dense } \\
\text { host populations, which will allow } \\
\text { for an increase in infection } \\
\text { parameters. }\end{array}$ & + & [14-20] \\
\hline
\end{tabular}




\section{References, relating to Table S2.}

1. De Castro, F., \& Bolker, B. (2005). Mechanisms of disease-induced extinction. Ecology Letters, 8(1), 117-126. doi: 10.1111/j.1461-0248.2004.00693.x

2. Briggs, C. J., Vredenburg, V. T., Knapp, R. A., \& Rachowicz, L. J. (2005). Investigating the population level effects of chytridiomycosis: an emerging infectious disease of amphibians. Ecology, 86(12), 3149-3159. doi: 10.1890/04-1428

3. Rachowicz, L. J., \& Briggs, C. J. (2007). Quantifying the disease transmission function: effects of density on Batrachochytrium dendrobatidis transmission in the mountain yellow legged frog Rana muscosa. Journal of Animal Ecology, 76(4), 711-721. doi: 10.1111/j.1365-2656.2007.01256.x

4. Briggs, C. J., Knapp, R. A., \& Vredenburg, V. T. (2010). Enzootic and epizootic dynamics of the chytrid fungus pathogen of amphibians. Proceedings of the National Academy of Sciences of the USA, 107(21), 9695-9700. doi: 10.1073/pnas.0912886107

5. Kriger, K. M., \& Hero, J. M. (2007). The chytrid fungus Batrachochytrium dendrobatidis is non-randomly distributed across amphibian breeding habitats. Diversity and Distributions, 13(6), 781-788. doi: 10.1111/j.1472-4642.2007.00394.x

6. Sapsford, S. J., Alford, R. A., \& Schwarzkopf, L. (2013). Elevation, temperature, and aquatic connectivity all influence the infection dynamics of the amphibian chytrid fungus in adult frogs. PLoS ONE, 8, e82425. doi: 10.1371/journal.pone.0082425

7. Piotrowski, J. S., Annis, S. L., \& Longcore, J. E. (2004). Physiology of Batrachochytrium dendrobatidis, a chytrid pathogen of amphibians. Mycologia, 96(1), 9-15. doi: $10.2307 / 3761981$ 
8. Puschendorf, R., Carnaval, A. C., VanDerWal, J., Zumbado-Ulate, H., Chaves, G., Bolaños, F., \& Alford, R. A. (2009). Distribution models for the amphibian chytrid Batrachochytrium dendrobatidis in Costa Rica: proposing climatic refuges as a conservation tool. Diversity and Distributions, 15(13), 401-408. doi: 10.1111/j.14724642.2008.00548.x

9. Lips, K. R. (1998). Decline of a tropical montane amphibian fauna. Conservation Biology, 12(1), 106-117. doi: 10.1111/j.1523-1739.1998.96359.x

10. Berger, L., Speare, R., Hines, H. B., Marantelli, G., Hyatt, A. D., McDonald, K. R., ... Tyler, M. J. (2004). Effect of season and temperature on mortality in amphibians due to chytridiomycosis. Australian Veterinary Journal, 82(7), 434-439. doi: 10.1111/j.1751-0813.2004.tb11137.x

11. Lips, K. R., Brem, F., Brenes, R., Reeve, J. D., Alford, R. A., Voyles, J., .. Collins, J. P. (2006). Emerging infectious disease and the loss of biodiversity in a Neotropical amphibian community. Proceedings of the National Academy of Sciences of the USA, 103(9), 3165-3170. doi: 10.1073/pnas.0506889103

12. Woodhams, D. C., \& Alford, R. A. (2005). Ecology of chytridiomycosis in rainforest stream frog assemblages of tropical Queensland. Conservation Biology, 19(5), 14491459. doi: 10.1111/j.1523-1739.2005.004403.x

13. Lampo, M., Rodriguez-Contreras, A., La Marca, E., \& Daszak, P. (2006). A chytridiomycosis epidemic and a severe dry season precede the disappearance of Atelopus species from the Venezuelan Andes. Herpetological Journal, 16(14), 395-402.

14. Balkenhol, N., \& Waits, L. P. (2009). Molecular road ecology: exploring the potential of genetics for investigating transportation impacts on wildlife. Molecular Ecology, 18(20), 4151-4164. doi: 10.1111/j.1365-294X.2009.04322.x 
15. Gibbs, J. P., \& Breisch, A. R. (2001). Climate warming and calling phenology of frogs near Ithaca, New York, 1900 - 1999. Conservation Biology, 15(4), 1175-1178. doi: 10.1046/j.1523-1739.2001.0150041175.x

16. Lesbarrères, D., Pagano, A., \& Lodé, T. (2003). Inbreeding and road effect zone in a Ranidae: the case of Agile frog, Rana dalmatina Bonaparte, 1840. Comptes Rendus Biologies, 326, 68-72. doi: 10.1016/S1631-0691(03)00040-4

17. Lesbarrères, D., Primmer, C. R., Lodé, T., \& Merilä, J. (2006). The effects of 20 years of highway presence on the genetic structure of Rana dalmatina populations. $\begin{array}{llll}\text { Ecoscience, } & \text { 13(4), } & \text { 531-538. } & \text { doi: }\end{array}$ 6860(2006)13[531:TEOYOH]2.0.CO;2

18. Vos, C. C., \& Chardon, J. P. (1998). Effects of habitat fragmentation and road density on the distribution pattern of the moor frog Rana arvalis. Journal of Applied Ecology, 35(1), 44-56. doi: 10.1046/j.1365-2664.1998.00284.x

19. Houlahan, J. E., \& Findlay, C. S. (2003). The effects of adjacent land use on wetland amphibian species richness and community composition. Canadian Journal of Fisheries and Aquatic Sciences, 60, 1078-1094. doi: 10.1139/f03-095

20. St-Amour, V., Wong, W. M., Garner, T. W. J., \& Lesbarrères, D. (2008). Anthropogenic influence on prevalence of 2 amphibian parasites. Emerging Infectious Diseases, 14(7), 1175-1176. doi: 10.3201/eid1407.070602 


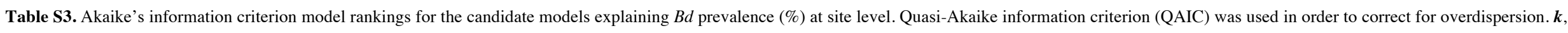

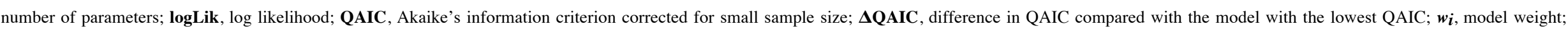

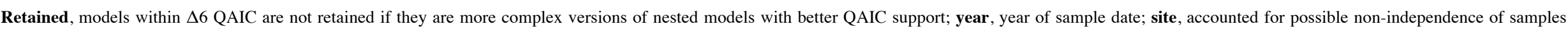

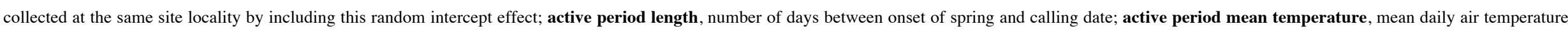

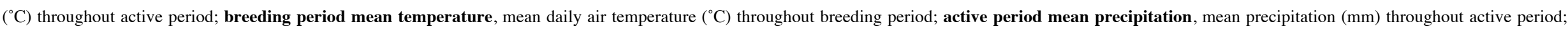

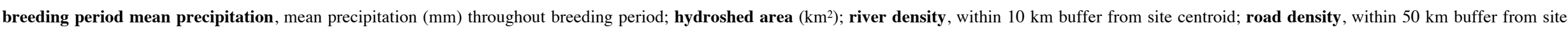
centroid.

\begin{tabular}{|c|c|c|c|c|c|c|c|}
\hline Model & Model description & $\boldsymbol{k}$ & logLik & QAIC & $\triangle Q \mathbf{Q A C}$ & $w_{i}$ & Retained \\
\hline $\mathrm{m} 1$ & factor(year) + active period length $*$ active period mean temperature $+(1$ I site $)$ & 7 & -167.08 & 67.78 & 0.000 & 0.107 & $\sqrt{ }$ \\
\hline $\mathrm{m} 20$ & factor(year) + active period mean temperature $+(1$ I site $)$ & 5 & -180.13 & 67.82 & 0.042 & 0.105 & $\sqrt{ }$ \\
\hline $\mathrm{m} 2$ & factor(year) + active period mean temperature + active period mean precipitation $+(1$ I site $)$ & 6 & -174.17 & 67.97 & 0.195 & 0.097 & $x$ \\
\hline m31 & factor(year) + breeding period mean temperature $+(1 \mid$ site $)$ & 5 & -182.56 & 68.57 & 0.796 & 0.072 & $\sqrt{ }$ \\
\hline $\mathrm{m} 25$ & factor(year) $+(1 \mid$ site $)$ & 4 & -190.04 & 68.89 & 1.113 & 0.062 & $\sqrt{ }$ \\
\hline m5 & factor(year) + active period length $*$ active period mean precipitation $+(1 \mid$ site $)$ & 7 & -171.66 & 69.20 & 1.420 & 0.053 & $x$ \\
\hline $\mathrm{m} 21$ & factor(year) + active period mean precipitation $+(1 \mid$ site $)$ & 5 & -186.02 & 69.64 & 1.867 & 0.042 & $x$ \\
\hline $\mathrm{m} 3$ & factor(year) + active period mean temperature + hydroshed area $+(1$ I site $)$ & 6 & -179.75 & 69.70 & 1.925 & 0.041 & $x$ \\
\hline $\mathrm{m} 4$ & factor(year) + active period mean temperature + river density $+(1 \mid$ site $)$ & 6 & -179.78 & 69.71 & 1.934 & 0.041 & $x$ \\
\hline $\mathrm{m} 18$ & factor(year) + active period mean temperature + road density $+(1 \mid$ site $)$ & 6 & -180.06 & 69.80 & 2.023 & 0.039 & $x$ \\
\hline m19 & factor(year) + breeding period mean precipitation $+(1 \mid$ site $)$ & 5 & -187.22 & 70.02 & 2.241 & 0.035 & $x$ \\
\hline $\mathrm{m} 28$ & factor(year) + breeding period mean temperature + hydroshed area $+(1$ I site $)$ & 6 & -181.89 & 70.36 & 2.588 & 0.029 & $x$ \\
\hline $\mathrm{m} 29$ & factor(year) + breeding period mean temperature + river density + (1 I site $)$ & 6 & -182.21 & 70.46 & 2.687 & 0.028 & $x$ \\
\hline $\mathrm{m} 27$ & factor(year) + breeding period mean temperature + breeding period mean precipitation $+(1 \mid$ site $)$ & 6 & -182.43 & 70.53 & 2.757 & 0.027 & $X$ \\
\hline $\mathrm{m} 30$ & factor(year) + breeding period mean temperature + road density $+(1$ I site $)$ & 6 & -182.53 & 70.56 & 2.788 & 0.027 & $x$ \\
\hline $\mathrm{m} 24$ & factor(year) + hydroshed area $+(1 \mid$ site $)$ & 5 & -189.31 & 70.66 & 2.888 & 0.025 & $x$ \\
\hline $\mathrm{m} 22$ & factor(year) + river density $+(1 \mid$ site $)$ & 5 & -189.72 & 70.79 & 3.016 & 0.024 & $x$ \\
\hline $\mathrm{m} 23$ & factor(year) + road density + (1 I site $)$ & 5 & -189.96 & 70.87 & 3.091 & 0.023 & $x$ \\
\hline m6 & factor(year) + active period mean precipitation + hydroshed area $+(1 \mid$ site $)$ & 6 & -185.40 & 71.45 & 3.676 & 0.017 & $x$ \\
\hline $\mathrm{m} 17$ & factor(year) + active period mean precipitation + road density $+(1 \mid$ site $)$ & 6 & -185.77 & 71.57 & 3.790 & 0.016 & $x$ \\
\hline $\mathrm{m} 7$ & factor(year) + active period mean precipitation + river density $+(1$ I site $)$ & 6 & -185.88 & 71.60 & 3.826 & 0.016 & $x$ \\
\hline $\mathrm{m} 12$ & factor(year) + breeding period mean precipitation + hydroshed area $+(1$ I site $)$ & 6 & -186.10 & 71.67 & 3.892 & 0.015 & $X$ \\
\hline $\mathrm{m} 16$ & factor(year) + road density + breeding period mean precipitation $+(1 \mid$ site $)$ & 6 & -187.07 & 71.97 & 4.193 & 0.013 & $x$ \\
\hline $\mathrm{m} 11$ & factor(year) + river density + breeding period mean precipitation $+(1$ I site $)$ & 6 & -187.15 & 71.99 & 4.218 & 0.013 & $X$ \\
\hline $\mathrm{m} 15$ & factor $($ year $)+$ road density $*$ breeding period mean precipitation $+(1$ I site $)$ & 7 & -184.07 & 73.04 & 5.263 & 0.008 & $x$ \\
\hline $\mathrm{m} 9$ & factor(year) + river density + breeding period mean precipitation + hydroshed area $+(1 \mid$ site $)$ & 7 & -185.99 & 73.63 & 5.858 & 0.006 & $X$ \\
\hline $\mathrm{m} 14$ & factor(year) + road density + breeding period mean precipitation + hydroshed area $+(1$ I site $)$ & 7 & -186.00 & 73.64 & 5.863 & 0.006 & $x$ \\
\hline $\mathrm{m} 10$ & factor(year) + river density $*$ breeding period mean precipitation $+(1 \mid$ site $)$ & 7 & -186.19 & 73.70 & 5.922 & 0.006 & $x$ \\
\hline $\mathrm{m} 13$ & factor(year) + road density $*$ breeding period mean precipitation + hydroshed area $+(1$ I site $)$ & 8 & -182.81 & 74.65 & 6.874 & 0.003 & $X$ \\
\hline $\mathrm{m} 8$ & factor(year) + river density $*$ breeding period mean precipitation + hydroshed area $+(1 \mid$ site $)$ & 8 & -184.68 & 75.23 & 7.453 & 0.003 & $x$ \\
\hline $\mathrm{m} 26$ & $1+(1 \mid$ site $)$ & 2 & -269.89 & 89.64 & 21.860 & 0.000 & \\
\hline
\end{tabular}




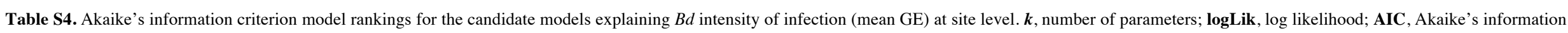

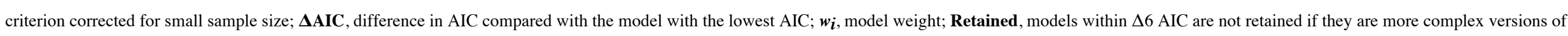

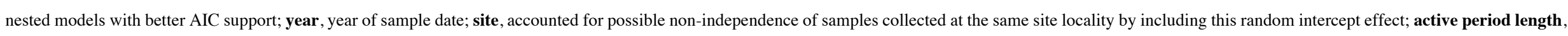

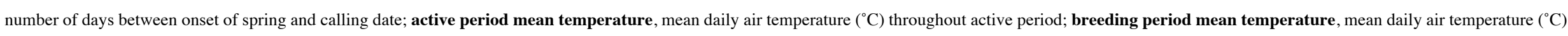

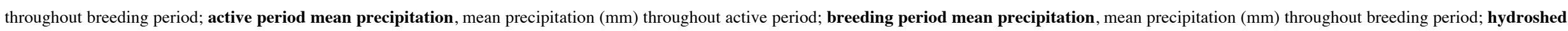
area $\left(\mathrm{km}^{2}\right)$; river density, within $10 \mathrm{~km}$ buffer from site centroid; road density, within $50 \mathrm{~km}$ buffer from site centroid.

\begin{tabular}{|c|c|c|c|c|c|c|c|}
\hline Model & Model description & $\boldsymbol{k}$ & logLik & AIC & $\Delta \mathrm{AIC}$ & $W_{i}$ & Retained \\
\hline $\mathrm{m} 8$ & factor(year) + river density $*$ breeding period mean precipitation + hydroshed area $+(1$ I site $)$ & 9 & -132.27 & 282.53 & 0.000 & 0.210 & $\sqrt{ }$ \\
\hline $\mathrm{m} 24$ & factor(year) + hydroshed area + (1 I site $)$ & 6 & -135.27 & 282.53 & 0.000 & 0.210 & $\sqrt{ }$ \\
\hline $\mathrm{m} 28$ & factor(year) + breeding period mean temperature + hydroshed area $+(1 \mid$ site $)$ & 7 & -135.03 & 284.06 & 1.530 & 0.098 & $x$ \\
\hline m3 & factor(year) + active period mean temperature + hydroshed area $+(1 \mid$ site $)$ & 7 & -135.16 & 284.32 & 1.792 & 0.086 & $x$ \\
\hline m12 & factor(year) + breeding period mean precipitation + hydroshed area $+(1 \mid$ site $)$ & 7 & -135.20 & 284.40 & 1.870 & 0.082 & $x$ \\
\hline m6 & factor(year) + active period mean precipitation + hydroshed area $+(1 \mid$ site $)$ & 7 & -135.21 & 284.41 & 1.880 & 0.082 & $x$ \\
\hline m9 & factor(year) + river density + breeding period mean precipitation + hydroshed area $+(1 \mid$ site $)$ & 8 & -135.15 & 286.31 & 3.774 & 0.032 & $x$ \\
\hline m14 & factor(year) + road density + breeding period mean precipitation + hydroshed area $+(1$ I site $)$ & 8 & -135.16 & 286.33 & 3.796 & 0.031 & $x$ \\
\hline $\mathrm{m} 25$ & factor(year) + (1 I site $)$ & 5 & -138.47 & 286.94 & 4.404 & 0.023 & $\sqrt{ }$ \\
\hline $\mathrm{m} 10$ & factor(year) + river density $*$ breeding period mean precipitation $+(1$ I site $)$ & 8 & -135.94 & 287.88 & 5.348 & 0.014 & $x$ \\
\hline $\mathrm{m} 13$ & factor(year) + road density $*$ breeding period mean precipitation + hydroshed area $+(1 \mid$ site $)$ & 9 & -135.15 & 288.30 & 5.764 & 0.012 & $x$ \\
\hline m31 & factor(year) + breeding period mean temperature $+(1 \mathrm{I}$ site $)$ & 6 & -138.17 & 288.35 & 5.814 & 0.011 & $x$ \\
\hline $\mathrm{m} 20$ & factor(year) + active period mean temperature $+(1 \mathrm{I}$ site $)$ & 6 & -138.21 & 288.42 & 5.888 & 0.011 & $X$ \\
\hline $\mathrm{m} 27$ & factor(year) + breeding period mean temperature + breeding period mean precipitation $+(1$ I site $)$ & 7 & -137.24 & 288.49 & 5.954 & 0.011 & $X$ \\
\hline m19 & factor(year) + breeding period mean precipitation $+(1 \mid$ site $)$ & 6 & -138.28 & 288.56 & 6.032 & 0.010 & \\
\hline $\mathrm{m} 22$ & factor(year) + river density + (1 I site $)$ & 6 & -138.36 & 288.71 & 6.182 & 0.010 & \\
\hline $\mathrm{m} 21$ & factor(year) + active period mean precipitation $+(1 \mid$ site $)$ & 6 & -138.37 & 288.74 & 6.206 & 0.009 & \\
\hline $\mathrm{m} 23$ & factor(year) + road density + (1 I site $)$ & 6 & -138.38 & 288.75 & 6.220 & 0.009 & \\
\hline $\mathrm{m} 29$ & factor(year) + breeding period mean temperature + river density + (1 I site $)$ & 7 & -138.01 & 290.01 & 7.482 & 0.005 & \\
\hline $\mathrm{m} 30$ & factor(year) + breeding period mean temperature + road density + (1 I site $)$ & 7 & -138.04 & 290.08 & 7.550 & 0.005 & \\
\hline $\mathrm{m} 18$ & factor(year) + active period mean temperature + road density $+(1$ I site $)$ & 7 & -138.07 & 290.14 & 7.610 & 0.005 & \\
\hline m5 & factor(year) + active period length $*$ active period mean precipitation $+(1 \mathrm{I}$ site $)$ & 8 & -137.14 & 290.28 & 7.752 & 0.004 & \\
\hline $\mathrm{m} 4$ & factor(year) + active period mean temperature + river density + (1 I site $)$ & 7 & -138.16 & 290.32 & 7.788 & 0.004 & \\
\hline $\mathrm{m} 2$ & factor(year) + active period mean temperature + active period mean precipitation $+(1 \mid$ site $)$ & 7 & -138.19 & 290.38 & 7.850 & 0.004 & \\
\hline m1 & factor(year) + active period length $*$ active period mean temperature $+(1 \mid$ site $)$ & 8 & -137.21 & 290.41 & 7.878 & 0.004 & \\
\hline m11 & factor(year) + river density + breeding period mean precipitation $+(1 \mid$ site $)$ & 7 & -138.21 & 290.43 & 7.896 & 0.004 & \\
\hline m16 & factor(year) + road density + breeding period mean precipitation + (1 I site $)$ & 7 & -138.23 & 290.47 & 7.934 & 0.004 & \\
\hline $\mathrm{m} 7$ & factor(year) + active period mean precipitation + river density $+(1 \mid$ site $)$ & 7 & -138.31 & 290.62 & 8.088 & 0.004 & \\
\hline $\mathrm{m} 17$ & factor(year) + active period mean precipitation + road density $+(1$ I site $)$ & 7 & -138.33 & 290.66 & 8.130 & 0.004 & \\
\hline $\mathrm{m} 15$ & factor $($ year $)+$ road density $*$ breeding period mean precipitation $+(1 \mid$ site $)$ & 8 & -138.12 & 292.24 & 9.706 & 0.002 & \\
\hline $\mathrm{m} 26$ & $1+(1 \mid$ site $)$ & 3 & -145.88 & 297.76 & 15.232 & 0.000 & \\
\hline
\end{tabular}

